KS. WOJCIECH ZAWADZKI* - WARSZAWA

\title{
KSIĘGOZBIÓR KLASZTORU BERNARDYŃSKIEGO W KADYNACH W ZASOBACH BIBLIOTEKI ELBLĄSKIEJ
}

Gromadzone przez stulecia księgozbiory były zewnętrznym przejawem poziomu intelektualnego, wykształcenia oraz statusu materialnego ich właścicieli. Wiele mówiły też o światopoglądzie, wyznawanej religii, poglądach politycznych, zainteresowaniach i kompetencjach, a nawet o życiu duchowym czytelników. Zazwyczaj ograniczano dostępu do bibliotek, nie były to czytelnie publiczne, a zasady korzystania z książek ustalali ich właściciele. Zresztą, umiejętność czytania i pisania, przez wieki dostępna tylko nielicznej grupie społeczeństwa, określała wąskie grono korzystających z księgozbiorów.

$\mathrm{Na}$ terenie dawnych Prus Królewskich i Prus Książęcych, książki gromadziły zamożne rody ${ }^{1}$, instytucje lokalnej władzy, w tym rady miejskie ${ }^{2}$, ośrodki edukacyjne $^{3}$ oraz instytucje religijne różnych wyznań. Spośród tych ostatnich, największe i dobrze skatalogowane biblioteki posiadały kapituły katedralne i kolegiackie, rezydencje biskupie, przykatedralne kolegia wikariuszowskie, seminaria duchowne i placówki zakonne. Bogatymi księgozbiorami mogły poszczycić się również niektóre parafie wielkomiejskie ${ }^{4}$. Parafie wiejskie posiadały w swych zbiorach z reguły kilka lub kilkanaście inkunabułów, chociaż i tu zdarzały się wyjątki. Za szczególnie bogatą w książki od XIV wieku, uchodziła biblioteka parafialna

* Ks. Wojciech Zawadzki - dr hab. nauk teologicznych, profesor w Instytucie Nauk Historycznych UKSW, dyrektor Archiwum Diecezji Elbląskiej, e-mail: w.zawadzki@uksw.edu.pl

${ }^{1}$ Bogata biblioteka w minionych stuleciach znajdowała się w pałacu w Waplewie. Por. A. Bukowski, Waplewo. Zapomniana placówka kultury polskiej na Pomorzu Nadwiślańskim, Wrocław 1989, s. 153-170; J. Wijaczka, Albrecht von Brandenburg-Ansbach (1490-1568). Ostatni mistrz zakonu krzyżackiego i pierwszy książe w „,Prusiech”, Olsztyn 2010, s. 243-246.

${ }^{2}$ Katalog der Stadtbibliothek zu Elbing, Bd. 1-2, bearb. L. Neubaur, Elbing 1893-1894; M. Józefczyk, Średniowiecze Elblaga, Elbląg 1996, s. 102.

${ }^{3}$ Bibliotekę miała królewiecka Albertyna, seminaria duchowne w Braniewie i Chełmnie, braniewski Alumnat Papieski, gimnazja w Braniewie, Chełmnie, Elblągu, Gdańsku, Reszlu i Toruniu.

${ }^{4}$ Józefczyk, Średniowiecze Elbląa, s. 10, 86, 95, 99, 102, 116. 
w Sątopach na Warmii ${ }^{5}$. Prywatne księgozbiory posiadali także niektórzy duchowni'.

Szczególnie bogate były biblioteki zakonne. Jednak od początku XX wieku wielu badaczy bibliotek klasztornych na terenie Rzeczypospolitej, podkreślało brak obszernych i całościowych opracowań dotyczących tej problematyki. Po upływie dziesięcioleci opinia ta nadal pozostaje aktualna. Opublikowano wprawdzie wiele monografii, ale poświęconych księgozbiorom w konkretnych placówkach zakonnych, głównie na terenie Małopolski, Śląska oraz ziemi lubelskiej, kieleckiej i lwowskiej. Jest to jednak dopiero wstęp do badań na polskimi bibliotekami klasztornym, gdy uświadomimy sobie, że w 1772 roku istniało w Polsce 995 męskich i 155 żeńskich domów zakonnych? 7 .

Jeszcze gorzej przedstawia się stan badań nad bibliotekami klasztornymi w dawnych Prusach Królewskich. Nie ma dotąd opracowania syntetycznego. Nie ma nawet monografii prezentujących księgozbiory w poszczególnych konwentach zakonnych. Literatura na ten temat jest bardzo skromna i ma charakter przyczynkarski ${ }^{8}$. Nadal, pomimo upływu ponad 50 lat, do ważniejszych publikacji należy artykuł Edmunda Piszcza o bibliotece reformackiej w Łąkach Bratiańskich ${ }^{9}$ oraz artykuł Mirosława Lademanna o bibliotece reformackiej w Wejherowie ${ }^{10}$. Przed badaczami stoi więc ogrom pracy, bo chociaż życie zakonne w Prusach Królewskich zawsze było słabo rozwinięte, jednak przed 1772 rokiem istniało na tym terenie 38 męskich i 13 żeńskich domów zakonnych ${ }^{11}$.

Zasady gromadzenia i przechowywania książek w klasztorach regulowane były statutami i konstytucjami. Chociaż w poszczególnych zakonach różniły się one między sobą, można też mówić o pewnych podobieństwach. Okazją do rewidowania klasztornych księgozbiorów były wizytacje władz zakonnych oraz każdorazowe zmiany przełożonego i bibliotekarza w konwencie. Ponieważ sytuacje

${ }^{5}$ Opis bibliotek kościelnych w diecezji warmińskiej zamieścił A. Kopiczko, Duchowieństwo katolickie diecezji warmińskiej w latach 1525-1821, T. I, Opracowanie prozopograficzne, Olsztyn 2000, s. 118-125; K.M. Kowalski, Księgozbiory parafialne archidiakonatu pomorskiego w XVIXVIII w., Studium z dziejów kultury intelektualnej Prus Królewskich, Gdańsk 1993.

${ }^{6}$ Zachował się katalog książek po zmarłym proboszczu dzierzgońskim ks. Franciszku Józefie Neytzlichowskim. Por. W. Zawadzki, Duchowieństwo katolickie oficjalatu pomezańskiego w latach 1525-1821, Tom I, Studium prozopograficzne, Elbląg 2009, s. 181-184.

${ }^{7}$ S. Litak, Od reformacji do oświecenia. Kościót katolicki w Polsce nowożytnej, Lublin 1994, s. 184, 186; M. Lademann, Biblioteka klasztoru oo. reformatów w Wejherowie, „Studia Pelplińskie”, 27 (1998) s. 205-206.

${ }^{8}$ P. Czaplewski, Ważniejsze rękopisy poklasztornej biblioteki $w$ Świeciu, „Zapiski TNT” t. IV, nr 2, 1917, s. 55-56.

${ }^{9}$ Archiwum Państwowe w Gdańsku (dalej APG), 10/3112, k. 1-19; E. Piszcz, Biblioteka klasztoru oo. reformatów w Eąkach na Pomorzu, „Archiwa, Biblioteki i Muzea Kościelne”, 2 (1961) z. $1-2$.

${ }^{10}$ Lademann, Biblioteka klasztoru oo. reformatów w Wejherowie, s. 203-250.

${ }^{11}$ Zawadzki, Duchowieństwo katolickie oficjalatu pomezańskiego w latach 1525-1821, Tom I, s. 275-276, 282-283; M. Borkowska, Zakony żeńskie w Polsce w epoce nowożytnej, w: Dzieje chrześcijaństwa Polski i Rzeczypospolitej Obojga Narodów, red. J. Kłoczowski, Lublin 2010, s. 287-376. 
te zdarzały się cyklicznie i z dużą częstotliwością, miało to korzystny wpływ na porządek w bibliotekach klasztornych. Utrzymaniu porządku sprzyjało też przechowywanie książek w pomieszczeniach zamkniętych, nadzorowanych, chronionych przed postronnymi osobami oraz zakaz wynoszenia książek poza klasztor. Biblioteki klasztorne służyły wyłącznie zakonnikom i były ich własnością.

Biblioteki klasztorne wyszły na ogół nietknięte z zawirowań reformacji, chociaż niektóre placówki opustoszały. Od II połowy XVI wieku zacieśniły się więzi między dworami szlacheckimi i klasztorami, co owocowało prawdzią eksplozją nowych fundacji zakonnych. W konwentach zaś gromadzono nowe księgozbiory. Dopiero epoka oświecenia, szerząc antyklerykalizm i materializm, uderzyła bezpośrednio w życie zakonne a pośrednio w instytucję bibliotek klasztornych. Część intelektualistów wzgardziła ideałami i wartościami chrześcijańskimi, w tym także zakonnymi. Klasztory dla wielu stały się synonimem „ciemnogrodu”. Dochodziło nawet do sytuacji, że mnichów i biblioteki klasztorne ośmieszali katoliccy bisku$\mathrm{pi}^{12}$.

Na przełomie XVIII i XIX wieku zbiegł się na ziemiach polskich pragmatyzm francuski, pruski i rosyjski. Pierwszy na fali rewolucji francuskiej, realizował hasło nacjonalizacji i powszechnej dostępności bibliotek. W tym samym czasie zaborcy kasowali kolejne zakony. Losy klasztornych bibliotek były w tej sytuacji przesądzone. Przez Prusaków były one grabione, przyłączane do świeckich księgozbiorów lub sprzedawane przypadkowym nabywcom, przez Rosjan zaś uznawane za bezwartościowe, szybko ulegały zniszczeniu.

Zasoby biblioteczne w klasztorach koncentrowały się zazwyczaj wokół problematyki teologicznej i religijno-ascetycznej. Zakonnicy rozczytywali się w dziełach, które dawały im wiedzę i umiejętności potrzebne do spełniania obowiązków wynikających z powołania. Istotny filar życia duchowego w klasztorach zawsze stanowiła lectio divina. Tak rozumiana lektura stawała się przeżyciem modlitewnym i sposobem osobistego uświęcenia. $Z$ tego powodu półki biblioteczne w konwentach wypełniały dzieła teologiczne, biblijne, ascetyczne i patrystyczne. Rzadziej gromadzono książki filozoficzne, historyczne, homiletyczne i prawnicze. W wyjątkowy sposób traktowano jednak klasyków. Starożytnych tekstów chętnie używano bowiem do ćwiczenia łaciny i greki. Natomiast dzieła polskiej literatury bardzo rzadko pojawiały się w zakonnych bibliotekach ${ }^{13}$.

W historię Prus Królewskich szczególnie mocno wpisał się zakon franciszkański. Założył go na początku XIII wieku św. Franciszek z Asyżu. Historyczny rozwój zakonu franciszkańskiego doprowadził do wyobrębnienia się trzech autonomicznych rodzin zakonnych. Pierwszą z nich stanowią Bracia Mniejsi składający się z czterech odłamów obserwanckich: Braci Mniejszych Regularnej Obserwancji zwanych w Polsce bernardynami (Fratres Minores Regularis Observantiae), Braci Mniejszych Ściślejszej Obserwancji (Ordo Fratrum Minorum Strictioris Observantiae), reformatów (Ordo Fratrum Minorum Reformatorum) i rekolektów (Ordo Fratrum Minorum Recollectorum). Drugą rodzinę franciszkańską sta-

\footnotetext{
${ }^{12}$ I. Krasicki, Monachomachia czyli wojna mnichów, Warszawa 1985, s. 32-33.

${ }^{13}$ Lademann, Biblioteka klasztoru oo. reformatów w Wejherowie, s. 213-216.
} 
nowią Bracia Mniejsi Konwentualni (Ordo Fratrum Minorum Conventualium), trzecią zaś kapucyni (Ordo Fratrum Minorum Capuccinorum) oraz Trzeci Zakon Regularny (Tertius Ordo Regularis).

Na terenie Prus Królewskich istniało osiem konwentów bernardyńskich (Barczewo, Kadyny, Lubawa, Nowe, Stoczek Warmiński, Świecie, Torun, Zamarte), sześć konwentów reformatów (Brodnica, Dzierzgoń, Gdańsk Chełm, Grudziądz, Łąki Bratiańskie, Wejherowo), dwa konwenty franciszkanów konwentualnych (Chełmno, Chełmża) oraz jeden konwent kapucynów (Rywałd) ${ }^{14}$.

Franciszkanie zasłynęli z gromadzenia książek. Biblioteki franciszkańskie, także na terenie Prus Królewskich, powstawały i pomnażały swoje zbiory w znacznej mierze dzięki zapisom osób, które łożyły pieniądze na zakup książek lub ofiarowywały swoje własne księgozbiory. Drogą kupna domy zakonne uzupełniały swe zasoby książkami, których nie udało się zdobyć czy to przez przepisanie czy to przez ofiarę dobroczyńców. Klasztory sporządzały nawet spisy poszukiwanych dzieł. Konstytucje franciszkańskie nakazywały, by gwardianie w ciągu miesiąca od chwili objęcia stanowiska dokonali w obecności świadków spisu wszystkich książek znajdujących się w klasztorze. W pruskich konwentach reformatów nakazano, aby przełożeni kupowali najnowsze wydawnictwa. Prowincjał zaś podczas wizytacji miał kontrolować, ile pieniędzy wydaje dom na kupno książek do wspólnej biblioteki. Prawo zakonne nakazywało też, aby wszelkie darowizny, legaty i depozyty poczynione na rzecz poszczególnych zakonników obracać na zakup potrzebnych książek. W 1633 roku franciszkańska kapituła generalna domagała się, by każda biblioteka klasztorna miała swego bibliotekarza. Zazwyczaj bibliotekarzem ustanawiano jednego z ojców lektorów. Do jego obowiązków należała troska o wszystkie sprawy naukowe w klasztorze, o wykłady, starania o potrzebne książki, ale także o papier, atrament i pióra.

Przepisy biblioteczne różnych zakonów były do siebie podobne. Strukturę bibliotek franciszkańskich określały przepisy ustanawiane na kongregacjach zakonnych a zawarte w statutach prowincji w artykule De bibliothecis conventuum. Przepisy te zezwalały zakonnikom wypożyczanie książek i zabieranie ich do celi. Zakonnik zobowiązany był pozostawić w bibliotece kartkę z opisem książki (autor i tytuł) i z własnoręcznym podpisem. Kartkę tę zwracano czytelnikowi z chwilą oddania książki, co pod karą nieposłuszeństwa należało uczynić przed każdą kongregacją i kapitułą zakonną. Kartki biblioteczne były gromadzone i tworzyły kartotekę rewersów. Za łamanie przepisów o bibliotekach franciszkanie przewidywali karę pozbawienia głosu czynnego i biernego, a nawet ekskomunikę zarezerwowaną prowincjałowi.

Biblioteki franciszkańskie podzielone były na kilkanaście działów: Ascetici Libri, Biblia, Expositores Sae Scripturae, Libri Controversistici, Libri Grammatici, Libri Historici, Libri Iuridici, Medicinales Libri, Libri Naturales, Libri Oratori, Praedicatores Latini, Praedicatores Polonici, Praedicatores Germanici, Libri Philosophici, Libri Regulares, Theologi Speculativi, Theologi Morales, Libri Poetarum, Libri Manu Scripti. W obrębie każdego z działów prowadzona była ciągła numeracja książek ${ }^{15}$.

${ }^{14}$ W. Zawadzki, Dzieje klasztoru bernardyńskiego w Kadynach, Olsztyn 2002, s. 19.

${ }^{15}$ Lademann, Biblioteka klasztoru oo. reformatów w Wejherowie, s. 221-224, 229, 238; E. Lenart, Biblioteki bernardyńskie w Polsce od 2. połowy XV wieku do końca wieku XVIII, w: Pięćset 
W zbiorach Biblioteki Elbląskiej im. Cypriana Norwida, przechowywane są książki dawnej Biblioteki Miejskiej Elbląga sprzed 1945 roku. W 1947 roku ocalałe z pożogi wojennej woluminy zostały oddane w depozyt do Biblioteki Uniwersyteckiej w Toruniu. Książki te powróciły do Elbląga dopiero w 2002 roku. W 2010 roku, w ramach projektu współfinansowanego przez Ministerstwo Kultury i Dziedzictwa Narodowego, konserwacji zachowawczej poddano 2280 woluminów druków pochodzących z okresu od XV do XVII wieku. Natomiast w 2012 roku Biblioteka Elbląska prowadziła projekt pt. Konserwacja zachowawcza zbioru starych druków z XVIII wieku. W ramach projektu zabiegom konserwatorskim poddanych zostało łącznie 1321 woluminów druków z XVIII wieku. Poza pracami konserwatorskimi, prowadzono również badania nad opracowaniem księgozbioru pod kątem historycznym. Analizowano między innymi zapisy proweniencyjne i próbowano identyfikować znaki własnościowe książek. W ramach tych prac, mgr Ewa Chlebus, dyplomowany konserwator zbiorów zabytkowych Biblioteki Elbląskiej, wyodrębniła 124 woluminy (w tym 12 współoprawnych), będące niegdyś własnością biblioteki klasztoru franciszkanów bernardynów w Kadynach ${ }^{16}$.

Kadyny leżą nad Zalewem Wiślanym, na północ od Elbląga. Kojarzone są zazwyczaj z rezydencją cesarza pruskiego, który otrzymał na własność kadyński pałac 15 grudnia 1898 roku. Potem Kadyny rozsławiła tamtejsza fabryka majoliki. Jednak już w XVII wieku wioska za sprawą franciszkanów bernardynów była ważnym i prężnym ośrodkiem życia religijnego w diecezji warmińskiej. Konwent został erygowany 18 sierpnia 1683 roku dzięki staraniom Jana Teodora von Schliebena, wywodzącego się ze znanej i zasłużonej dla Prus szlacheckiej rodziny. Istotnym celem tworzonej placówki zakonnej miała być w przyszłości praca misyjna wśród luteran w okolicach Elbląga i Gdańska. W latach 1684-1749 zbudowano najpierw drewniane, a następnie murowane zabudowania klasztorne i kościół. Uroczystej konsekracji nowej świątyni dokonał 22 czerwca 1749 roku biskup sufragan chełmiński Jan Krasiński. W klasztorze na stałe zatrudnionych było kilkunastu ojców i braci zakonnych. Należy przypuszczać, że mieli wiele zajęć duszpasterskich, bowiem konwent kadyński na początku XVIII w. stał się znanym w regionie sanktuarium św. Antoniego Padewskiego. Kult św. Antoniego w Kadynach rozwinął się wokół obrazu patrona świątyni umieszczonego w jednym z bocznych ołtarzy w pobliżu prezbiterium. W całych Prusach znany był obchodzony w Kadynach doroczny odpust św. Antoniego Padewskiego. Uroczystości rozpoczynały się w dniu liturgicznego wspomnienia świętego 13 czerwca i trwały pełne 8 dni. Przybywały wówczas rzesze indywidualnych i zorganizowanych w grupy pątników. Wraz z nimi ściągali na kadyńskie wzgórze kramarze i drobni handlarze z budami i sklepikami, nadając uroczystościom religijnym charakteru ludowego jarmarku. Zorganizowane pielgrzymki przybywały do sanktua-

pięćdziesią lat obecności oo. bernardynów w Polsce (1453-2003), red. W.F. Murawiec, D.A. Muskus, Kalwaria Zebrzydowska 2006, s. 659-676.

${ }^{16}$ D. Czyżak, Zanim księgozbiór elbląski do Torunia dotart, „,Rocznik Elbląski”, 18 (2002) s. 141-148; D. Jutrzenka-Supryn, Zatożenia, problemy i realizacja konserwatorskiej ochrony zabytkowego księgozbioru w Bibliotece Elbląskiej, „Rocznik Elbląski”, 22 (2009) s. 299-314. 
rium z pobliskich wsi i miasteczek, jak również z bardziej odległych miejscowości niemal całej Warmii. Przy kadyńskim konwencie działały także cztery konfraternie religijne - Zwiastowania Najświętszej Maryi Panny, św. Anny, Paska św. Franciszka i św. Antoniego Padewskiego.

Klasztor bernardynów w Kadynach, podobnie jak inne placówki zakonne w państwie pruskim, padł ofiarą ustaw kasacyjnych. Król Fryderyk Wilhelm III wydał 30 października 1810 roku edykt sekularyzacyjny, skazujący pruskie klasztory na stopniową, lecz definitywną zagładę. Rozpoczęto akcję zamykania opustoszałych konwentów i kumulowania zakonników w innych klasztorach. Domy zakonne przejmowane przez państwo zamieniano na instytucje świeckie. Sporządzony w 1801 roku spis zakonników kadyńskich podaje, że w tym czasie klasztor zamieszkiwało jeszcze dziewięciu ojców oraz czterech braci zakonnych. Jednak likwidacja placówki była nieuchronna. Dzień ostatecznej kasaty klasztoru bernardyńskiego w Kadynach władze państwowe wyznaczyły na 6 kwietnia 1826 roku. W dalszej kolejności urzędnicy pruscy przystąpili do zabezpieczenia i rozdysponowania zakonnego i kościelnego majątku. Dosyć łatwo można zidentyfikować ich odbiorców, zachował się bowiem materiał archiwalny dotyczący tej problematyki ${ }^{17}$.

O wiele trudniejsze są do prześledzenia losy klasztornej biblioteki i archiwum. O ich dalszym losie decydowali pruscy urzędnicy i wydawane przez nich rozporządzenia. Mimo, że likwidację pruskich bibliotek zakonnych zakładano prowadzić planowo, w rzeczywistości odbywało się to w sposób chaotyczny. Władze poleciły, aby księgozbiory likwidowanych klasztorów przejrzeli najpierw sekretarze powiatowi. Mieli oni przesłać odpowiednie raporty do Ministerstwa Oświecenia oraz Biblioteki Królewskiej w Berlinie. Instytucje te otrzymały pierwszeństwo w wyborze potrzebnych im dzieł. Następnie prawo wyboru i przejęcia książek przysługiwało bibliotekom uniwersyteckim. Z góry więc zakładano dekompozycję bibliotek klasztornych w Prusach. To, co pozostawało, oddawano do dyspozycji lokalnego biskupa. Biskupi zaś najchętniej oddawali książki do bibliotek seminaryjnych.

Bibliotekarze i urzędnicy pruscy wyrządzili olbrzymią krzywdę kulturze dawnych Prus Wschodnich i Zachodnich. Często traktowali stare książki jako makulaturę. Biblioteki klasztorne wstępnie przetrzebione i zniszczone, zazwyczaj nadal pozostawały na swym miejscu bez właściwego zabezpieczenia. Wydelegowany w 1836 roku z Berlina na Pomorze komisarz ministerialny zwiedził poklasztorne biblioteki i wydał o nich opinię, że niegdyś były bardzo zasobne i starannie utrzymane. W wyniku kasat znacznie ucierpiały. Pomimo to z ośmiu bibliotek zakonnych z terenu diecezji chełmińskiej wybrał 13779 woluminów dla państwowych bibliotek w Berlinie. Wśród nich było wiele cennych inkunabułów ${ }^{18}$.

Zachowały się dwa archiwalne katalogi biblioteki kadyńskiej. Pierwszy został sporządzony w układzie alfabetycznym na 26 numerowanych stronach przez gwardiana Juliusza Heina i przesłany 25 października 1811 roku do regencji gdań-

\footnotetext{
${ }^{17}$ Zawadzki, Dzieje klasztoru bernardyńskiego w Kadynach, passim.

${ }^{18}$ Lademann, Biblioteka klasztoru oo. reformatów w Wejherowie, s. 233-234.
} 
skiej. Wynika z niego, że przed kasatą w bibliotece kadyńskiej przechowywano 1327 woluminów. W języku łacińskim było 859 woluminów, w tym in folio 244 woluminy, in quarto 194 , in octavo maiori 51 , in octavo minori 196 , in duodecimo 174. W języku niemieckim było 386 woluminów: in folio 51, in quarto 149, in octavo maiori 121, in octavo minori 65 woluminy. W języku polskim były 82 woluminy: in folio 16 , in quarto 26 , in octavo 40 woluminy ${ }^{19}$.

W oddzielnej szafie, poza biblioteką, bernardyni posiadali 29 woluminów prohibitów, a wśród nich między innymi: Historiae Belgicae (Amsterdami 1630), Hartknochel Historia Prusica (Lipsiae 1786), Cathechismus Lutheri (Elbingae 1774), Hildebrandi Cogitationes de Sanctis (Starogardi 1707), Roterrdami Opus de ratione concionandi (Antverpiae 1535). W refektarzu posługiwano się 11 księgami: Expositio Ludolphi super Evangelia, Vita Sacntorum (Coloniae 1726), Martini Cochem De vita Christi, Thomae a Kempis, Caeremoniale (Posnanie 1685), Regula Sancti Francisci scripta, Decreta Summorum Pontificum (Posnaniae 1770), Liber mortuorum (Varsaviae 1795), Statuta Provinciae S. Mariae Angelorum, Biblia Sacra (Lutetiae 1648), Marchantii Expositio in Regulam S. Francisci (Cracoviae 1637). W części chórowej kościoła zakonnego do codziennego użytku było dodatkowo 40 ksiąg liturgicznych: 2 Gradualia cum notis choralibus, 3 Antiphonaria cum notis choralibus, 1 Rituale sacramentorum, 1 Martyrologium, 9 Psalmi communes pro dicendis horis canonicis, 12 Breviara, 3 Cantionalia scripta cum notis, 2 Nova additamenta ad Breviaria, 2 Diurnalia in 4to, 5 Diurnalia in folio ${ }^{20}$.

W zasobach bibliotecznych w Kadynach przechowywano w 1811 roku 9 inkunabułów. Jeden z nich to Summa angelica de casibus conscientiae, cum additione Hieronymi Tornieli, Nürnberg, Antonius Koberger, 23 VIII 1498. 2021. Pozostałe inkunabuły to: Sperati opus de anima, Norymberga 1482; Sperati de Beata, Norymberga 1482; dwa woluminy Sperati Alexandrini opus, Norymberga 1482; dwa woluminy Sperati Alexandrini opus, Norymberga 1486; dwa woluminy Sperati Alexandrini opus, Norymberga $1487^{22}$.

W omawianym katalogu zdecydowanie przeważają woluminy wydane w XVI i XVII wieku. Mało jest książek wydanych w I połowie XVIII wieku - 179 woluminów, a jeszcze mniej z II połowy XVIII wieku - 124 woluminy. Są to w sumie 303 woluminy wydane w XVIII wieku, co przy ogólnej liczbie 1327 woluminów, stanowi mniej niż $25 \%$ całego zbioru.

Najmłodsza książka przechowywana w 1811 roku w bibliotece kadyńskiej to Libellus Concertantium, Poznań $1794^{23}$. Nie było natomiast ani jednej książki wydanej w XIX wieku²4.

\footnotetext{
${ }^{19}$ APG, 6/30.006, k. 31-73.
}

${ }^{20}$ APG, 10/3341, s. 70-71.

${ }^{21}$ W katalogu zapisano Clavasii de casibus conscientiae, Norymberga 1498. Inkunabuł znajduje się w Bibliotece Wyższego Seminarium Duchownego Metropolii Warmińskiej w Olsztynie. Por. APG, 10/3341, s. 91; J. Wojtkowski, Katalog inkunabułów Biblioteki Wyższego Seminarium Duchownego Metropolii Warmińskiej „Hosianum” w Olsztynie, Olsztyn 2007, s. 25.

${ }^{22}$ APG, 10/3341, s. 94; Wojtkowski, Katalog inkunabutów, s. 153.

${ }^{23}$ APG, 10/3341, s. 102.

${ }^{24}$ W. Zawadzki, Księgozbiory klasztorów franciszkańskich $w$ Prusach Zachodnich $w$ okresie ich kasaty, „Hereditas Monasteriorum”, 4 (2014), w druku. 
Biblioteka kadyńska podzieliła los innych pruskich konwentów. Z dokumentów archiwalnych wiadomo, że jeszcze w 1827 roku księgozbiór był nienaruszony. Potem przez kilka lat książki i dokumenty pozostawały w opuszczonym klasztorze. Na początku 1829 roku nauczyciel Albert Gehrmann sporządził drugi katalog biblioteki bernardyńskiej, który się nie zachował. Za swą pracę otrzymywał dniówkę 20 groszy, a w sumie wypłacono mu 2 talary 20 groszy. Jednak urzędnicy regencji gdańskiej skarżyli się nadprezydentowi von Schönowi, że w nowym katalogu jest dużo braków i nieścisłości. Wiele tytułów zostało przepisanych z błędami, a niejednokrotnie nie podano miejsca i roku wydania książek. Regencja oddała więc katalog do oceny zasobności i wartości biblioteki kadyńskiej radcy konsystorialnemu Gernhardowi. Radca także bardzo krytykował jakość sporządzonego katalogu. Jego zdaniem wiele książek nadawało się tylko na makulaturę, jednak niektóre „zasługiwały na lepszy los”. Wypisał 37 tytułów książek, które mogły mieć większą wartość: Martyrologium Romanum, Missale antiquum, inkunabuł dzieł św. Ambrożego z 1492 roku, Opera omnia św. Anzelma, Adversus nationes Arnobiusza z Sikka, Cezara Baroniusa Annales ecclesiastici, św. Bazylego Wielkiego dzieła w języku greckim i łacińskim, św. Bernarda z Clairvaux Opera omnia, św. Bonawentury Opera omnia, Izydora z Peluzjum Epistolae, Loius Dupina Nova bibliotheca, dzieła św. Cypriana, św. Cyryla, św. Damazego, św. Efrema Syryjczyka, św. Grzegorza z Nyssy, św. Hieronima, św. Hipolita, św. Ireneusza, Juliana z Eklanum, Optata z Milewe, Orygenesa, Teodoreta, Teofila, Tertuliana, św. Tomasza z Akwinu. W sumie było to kilkadziesiąt woluminów. Niemal przy każdym tytule Gernhard prosił o precyzyjne określnie miejsca i roku wydania książki. Zaznaczył też, że nie może ocenić wartości kilku książek w języku polskim, bo nie włada tym językiem. Jego wątpliwość wzbudziła też informacja zapisana na końcu katalogu o „,66 woluminach w bardzo złym stanie wydanych w różnych językach" i „11 rękopiśmiennych książkach po łacinie”. Należało więc, jego zdaniem, dokonać ponownego przeglądu wszystkich woluminów.

Gernhard zaproponował, by na miejscu w Kadynach do ponownego klasyfikowania książek zatrudnić proboszcza tolkmickiego i pastora z Łęcza. Mieli oni przede wszystkim ocenić wartość owych 11 łacińskich rękopisów, ewentualnie książek. Gdyby duchowni nie mogli pojawić się w Kadynach, Gernhard proponował, by księgozbiór w całości przetransportować do Elbląga. W Elblągu książki, mimo że nie sporządzono właściwego katalogu, miały zostać wystawione na aukcję, poza 61 woluminami wymienionymi przez Gernharda. Zastrzeżony zbiór 61 woluminów miał być dostarczony radcy konsystorialnemu.

Nadprezydent Schön w liście do ministerstwa w Berlinie z 24 czerwca 1829 roku pisał, że księgozbiór zostanie podzielony między biblioteką uniwersytecką w Królewcu (fakultet teologiczny), gimnazjum elbląskim i kapitułą warmińską. Na prośbę nadprezydenta Schöna książki przydatne w gimnazjum elbląskim, miał wyselekcjonować jego rektor Johann Georg Mund. Jednak minister Nicolovius proponował, by sporządzić nowy katalog książek, o ile nie pociągnie to za sobą znacznych wydatków. Zalecał, by przy niektórych książkach podać dokładną datę wydania. Schön pracę tę 5 sierpnia 1829 roku zlecił regencji gdańskiej. Wiadomo, że nowy katalog został spisany, ale i ten nie uzyskał uznania w ministerstwie 
w Berlinie. Dnia 31 gudnia 1829 roku nadprezydent otrzymał odpowiedź, że należy w pierwszej kolejności przekazać książki gimnazjum elbląskiemu i uniwersytetowi królewieckiemu a pozostałe woluminy można oddać kapitule warmińskiej.

Wiadomo, że kapitule przekazano, na jej życzenie, w czerwcu 1830 roku 12 brewiarzy, brewiarz warmiński (Breviarium Varmiense), 10 mszałów rzymskich oraz graduał rzymski. Książki przeznaczone dla biblioteki uniwersyteckiej w Królewcu miały zostać przewiezione statkiem i przekazane profesorowi Lobëk. Za ich transport odpowiadał nauczyciel Albert Gehrmann, dawny organista w konwencie kadyńskim ${ }^{25}$.

Pojedyncze egzemplarze kadyńskich archiwaliów odnajdywane są w bardzo oddalonych od siebie miejscach. Kronika domu zakonnego znalazła się w Archiwum Prowincji Bernardynów w Krakowie. Do zespołu archiwaliów tolkmickich przechowywanych w Archiwum Diecezji Warmińskiej w Olsztynie dołączono między innymi księgę bractw kadyńskich oraz księgę z odpisami listów nadsyłanych do konwentu. Jeden z warmińskich historyków odnalazł w 1913 roku w ówczesnym Archiwum Państwowym w Gdańsku (Staatsarchiv zu Danzig) dwie księgi z archiwum zakonnego w Kadynach. Jedna z nich nosiła tytuł: Archivum conventus Cadinensis ad S. Antonium Paduanum anno Dni 1682. Księga ta była oprawiona w brązową skórę, miała $10 \mathrm{~cm}$ grubości i zaledwie $1 / 8$ kartek została zapisana. Na stronie tytułowej był umieszczony wizerunek św. Antoniego Padewskiego. Druga z przechowywanych w archiwum ksiąg była wykazem zarządzeń bernardyńskich władz zakonnych. Wiadomo także, że część archiwum kadyńskiego oraz barczewskiego znalazła się w archiwum biskupim we Włocławku. W 1910 roku badał je kanonik warmiński Franz Dittrich. Niestety nie wiadomo, jakie to były księgi. Wszystkie zaginęly po II wojnie światowej ${ }^{26}$.

Część księgozbioru kadyńskiego w kwietniu 1830 roku została włączona do biblioteki gimnazjum elbląskiego, by potem znaleźć się w zasobach Biblioteki Miejskiej w Elblągu. Nie natrafiono jednak dotąd na katalog książek kadyńskich przekazanych w XIX wieku do Elbląga. Wiadomo jednak, że taki katalog został sporządzony. Zidentyfikowana przez mgr Ewę Chlebus grupa książek klasztoru kadyńskiego, jest pierwszą próbą rekonstrukcji księgozbioru bernardynów z Kadyn w elbląskich zbiorach bibliotecznych.

Do Muzeum Archeologiczno-Historycznego w Elblągu trafił starodruk, Graduale Romanum z XVII wieku ${ }^{27}$. Na stronie tytułowej umieszczone są dawne pieczęcie elbląskiego gimnazjum. Na jednej z kart znajduje się odręczny wpis informujący, że graduał został ofiarowany konwentowi kadyńskiemu przez kanonika Zachariasza Jana Szolca: „Conventui Cadinens[i] obtulit Perillustris et Reverend[us] D[ominus] Joannes Zacharias Szolcz Custos Warmien[sis]”. Skądinąd wiadomo, że Szolc przekazał tę księgę zakonnikom w 1692 roku. Jest wielce prawdopodobne, że własnością bernardynów w Kadynach było również przecho-

${ }^{25}$ APG, I 6/845 k. 385, 447-455, 467, 472-473, 490-513, 532; APG 495/697 k. 19.

${ }^{26}$ Zawadzki, Dzieje klasztoru bernardyńskiego w Kadynach, s. 141.

${ }^{27}$ Sygnatura ME/15/HS. Por. Katalog der Stadtbibliothek zu Elbing, Bd. 1, s. 190; Zawadzki, Dzieje klasztoru bernardyńskiego w Kadynach, s. 44. 
wywane w elbląskim muzeum Martyrologium Romanum, drukowane w Antwerpii w 1608 r. ${ }^{28}$ Może o tym świadczyć umieszczona na końcu rękopiśmienna wklejka pt. Praeintonationes Martirologii Festorum Ordinis Minoris per Menses totius anni currentium. Pojedyncze egzemplarze kadyńskich ksiąg mogły także trafić do okolicznych parafii ${ }^{29}$.

Bliżej nieokreśloną liczbę kadyńskich książek w XIX wieku przejęła kapituła warmińska we Fromborku. Za jej pośrednictwem książki te znalazły się współcześnie w zasobach Biblioteki Wyższego Seminarium Duchownego Metropolii Warmińskiej „Hosianum” w Olsztynie. Odnalezione zostały tam trzy kadyńskie inkunabuly:

1. Summa angelica de casibus conscientiae, cum additione Hieronymi Tornieli, Nürnberg, Antonius Koberger, 23 VIII 1498. $2^{\circ}$.

Proweniencja: a. Caroli Schrader 1726 die 26 Novembris.

b. Francisci Piekulij (XVIII wiek).

c. Cessit Conventui Cadinensi sancti Antonii Ordinis Minorum sancti Francisci Regularis Observantiae anno Domini 1741, die 1 Martii.

d. Bibliotheca Capituli Warmiensis Frauenburgi (pieczątka XX wiek).

sygnatura: Inc. 113.

2. Manipulus curatorum, Strasbourg, [Typ. Jordani = Georgius Husner], 29 XI 1490. $4^{\circ}$.

Proweniencja: a. Nieczytelna (XVI wiek)

b. Conventus Cadinensis Ordinis Minorum sancti Francisci Observantium (XVII wiek).

c. Dombibliothek Frauenburg (Exlibris XIX wiek).

d. Bibliotheca Capituli Warmiensis Frauenburg (pieczątka XX wiek).

sygnatura: Inc. 5,1 adl.

3. Sermones de tempore et de Sanctis, sive Hortulus reginae, P. I-III, Basel, Nicolaus Kessler, 20 I 1487. $2^{\circ}$.

Proweniencja: a. Istum librum legavit quondam dominus Nicolaus Swichtenbergk Minoribus in Warthenburgk, qui obiit anno Domini millesimo quingentesimo decimo octavo feria quarta sub octavis Pentecostes (26 V 1518).

b. Pro Conventu Cadinensi (XVII/XVIII wiek).

c. Dombibliothek Frauenburg (ekslibris XIX wiek)

d. Bibliotheca Capituli Warmiensis Frauenburg (pieczątka XX wiek). sygnatura: Inc. $100^{30}$.

W bibliotece seminaryjnej w Olsztynie znajdują się także kadyńskie starodruki. Skatalogowano dotąd tylko księgi z XVI wieku, a wśród nich zidentyfikowano

${ }^{28}$ Sygnatura ME/30/HS

${ }^{29}$ Ks. dr Infułat Mieczysław Józefczyk, w latach 80. XX wieku odnalazł na strychu plebanii w Pogrodziu starodruk z pieczęcią konwentu bernardyńskiego w Kadynach. Księga została podarowana ówczesnemu biskupowi warmińskiemu Janowi Obłąkowi.

${ }^{30}$ J. Obłąk, Z. Jaroszewicz-Pieresławcew, J. Wojtkowski, Katalog inkunabułów Biblioteki Wyższego Seminarium Duchownego Metropolii Warmińskiej „Hosianum” w Olsztynie, Olsztyn 2007, s. 25, nr 14; s. $68 \mathrm{nr} 125$; s. $93 \mathrm{nr} 188$. 
dwa współoprawne woluminy z Kadyn. Zawierają one siedem tytułów opracowanych przez czterech autorów:

1. Guillermus Parisiensis, Postilla super Evangelia de tempore et de sanctis, [?], post $1500.4^{\circ}$.

Proweniencja: a. Sum Benedicti Rebigij (XVI/XVIIw.)

b. Umyślnie zamazano atramentem

c. Nunc Martini Redlitij (+1671)

d. Nunc Conventus Cadinensis (XVII w.)

e. Bibliotheca Capituli Warmiensis Frauenburg (pieczątka XIX/XX w.)

Współoprawny z numerem 2, 3, 4 .

Sygnatura: XVI Q 016,1; dawna: Inc 4,1 adl.

2. Guillermus Parisiensis, Postilla super epistolas de tempore et de sanctis, Pars

II, [Basel, Nicolaus Keßler, ca 1501]. $4^{\circ}$.

Proweniencja jak numer 1.

Współoprawny z numerem 1, 3, 4.

Sygnatura: XVI Q 016,2; dawna: Inc 4,1 adl.

3. Passio Domini. - Pseudo-Bernardus Claravallensis s.: De planctu Beatae Mariae Virginis, [Basel, Michael Furter, ca 1501]. $4^{\circ}$.

Proweniencja jak numer 1.

Współoprawny z numerem 1, 2, 4.

Sygnatura: XVI Q 016,3; dawna: Inc 4,2 adl.

4. Torrentinus Hermannus, Hymni et sequentiae cum diligenti difficiliorum verborum interpretatione, [Zwolle, Petrus van Os 1502-1504]. $4^{\circ}$.

Proweniencja jak numer 1.

Współoprawny z numerem 1, 2, 3 .

Sygnatura: XVI Q 016,4; dawna: Inc 4,3 adl.

5. Clingius Conradus, De securitate conscientiae Catholicorum in rebus Fidei, Köln, Arnold Birckmann haeredes, 1563. $2^{\circ}$.

Proweniencja: a. floreni 3 . grossi 3.

b. Juvenes in ulbrick (XVI w.)

c. Reverendus Dominus Iacobus de Żnino me Sigismundo Humielski(?) testamento donavit. Requiescat in sempiterna Pace. Amen. (XVI w.)

d. Christophori Schmidt Canonici Gutstatensis: anno (15)93

e. Praedictus Dominus donavit P. Busau, qui iterum ipsum librum dedit Domino Georgio Engenbrecht in Glottau Amico suo singulari Anno Domini 1603

f. Librum hunc mihi oblatum relinquo in Conventu Cadinensi. 1691. 27 Junij. Frater Hieronymus Rochell, pleno titulo Vicarius loci

g. Bibliotheca Lycei Regii Hosiani (pieczątka XIX w.)

Współoprawny z numerem 6, 7 .

Sygnatura: De 218,1 adl.

6. Clingius Conradus, Catechismus Catholicus, Köln, Arnold Birckmann haeredes, $1562.2^{\circ}$.

Proweniencja jak numer 5.

Współoprawny z numerem 5, 7. 
Sygnatura: De 218,2 adl.

7. Clingius Conradus, Summa Doctrinae Christianae Catholicae, Köln, Arnold

Birckmann haeredes, 1562. $2^{\circ}$.

Proweniencja jak numer 5.

Współoprawny z numerem 5, 6.

Sygnatura: De 218,3 adl $^{31}$.

Odnaleziono także w bibliotece olsztyńskiej jeden starodruk kadyński pochodzący z XVII wieku: Antiphonarium Romanum de tempore et sanctis, Venetiis, apud Cieras, 1634. 2. W książce znajduje się zapis proweniencyjny: „Hoc Antiphonarium inutile Eccle[si]ae Parochiali Melsaccensi donatum est ad corum Ad[modu]m Reverendis Patribus Cadinensibus Ord[ini]s Minorum Sancti Francisci de observantia, de consensu et licentia R[everendissi]mi ac Perillustris D[omi]ni Zachariae Joannis Szolc Custodis Can[oni]ci Officialis Generalis Varmiensis eiusdemque E[pisco]patus Administratoris A[nno] D[omini] 1687 die 4 Februarij. Extradidi Simon Wagner Archipresbiter Melsacensis manu propria" 32 .

Zidentyfikowane i skatalogowane w Bibliotece Elbląskiej 124 woluminy kadyńskie, stanowią zaledwie niewielką część pierwotnego księgozbioru ${ }^{33}$. Pewne wyobrażenie o zasobności biblioteki konwentu w Kadynach, dają zachowane katalogi innych bibliotek franciszkańskich w Prusach Zachodnich. Biblioteka klasztoru reformatów w Wejherowie przed jej likwidacją w 1836 roku liczyła 692 woluminy $^{34}$. Księgozbiór bernardynów z Lubawy w XIX wieku liczył 2046 woluminów ${ }^{35}$. Biblioteka reformatów w Dzierzgoniu w 1835 roku zawierała 695 woluminów $^{36}$. Księgozbiór bernardynów w Świeciu, według katalogu z 18 marca 1812 r. liczył 722 woluminy ${ }^{37}$. W klasztorze reformatów w Łąkach przechowywano 1339

${ }^{31}$ J. Wojtkowski, Katalog druków XVI wieku Biblioteki Wyższego Seminarium Duchownego Metropolii Warmińskiej „Hosianum” w Olsztynie, Lublin 2012.

${ }^{32}$ Biblioteka WSD „Hosianum” w Olsztynie sygnatura: II-3001/2.

${ }^{33}$ Przed kasatą biblioteka kadyńska liczyła ponad 500 woluminów. Świadczy o tym katalog sporządzony w 1829 roku na polecenie landrata Abramowskiego. Radca konsystorialny Gernhard zaznaczył w nim niektóre woluminy. Ostatnia z książek oznaczona była w katalogu numerem 493. Por. APG, I 6/845 k. 453.

${ }^{34}$ Lademann, Biblioteka klasztoru oo. reformatów w Wejherowie, s. 234, 238.

${ }^{35}$ Zawadzki, Księgozbiory klasztorów franciszkańskich $w$ Prusach Zachodnich $w$ okresie ich kasaty, „Hereditas Monasteriorum”, 4 (2014), w druku. [strony]

${ }^{36}$ Dnia 25 sierpnia 1837 roku proboszcz dzierzgoński Elwart doliczył się w księgozbiorze dzierzgońskim zaledwie 200 woluminów. Por. AAWO, AB III, C 8, Reformaten Kloster zu Christburg 1822-1843, k. 223-224, 239v; APG, 10/2776, s. 79, 204-206.

37 Zachował się bardzo szczegółowy, usystematyzowany alfabetycznie katalog książek, sporządzony dla władz pruskich przez definitora zakonnego ze Świecia o. Krescencjusza Schenka. Por. APG, 10/4537, k. 42-58; Czaplewski, Ważniejsze rękopisy poklasztornej biblioteki w Świeciu, s. $55-56$. 
woluminów ${ }^{38}$. Reformaci w Brodnicy posiadali 1567 woluminów ${ }^{39}$. Według spisu, sporządzonego 13 maja 1817 roku przez gwardiana Rafała Tronowskiego, w bibliotece klasztornej kapucynów w Rywałdzie znajdowały się 1244 woluminy ${ }^{40}$. Gwardian konwentu bernardynów w Toruniu Faustyn Lentecki, przedstawił władzom najpierw katalog 156 książek wydanych wyłącznie w języku niemieckim ${ }^{41}$, a następnie 23 sierpnia 1817 roku, dołączył katalog pozostałych 677 książek bernardynów toruńskich, wydanych w języku łacińskim i polskim ${ }^{42}$. W sumie konwent toruński posiadał 833 woluminy.

Zachowały się również katalogi biblioteczne kilku innych pruskich klasztorów. Dominikanie w Chełmnie, według spisu z 20 kwietnia 1817 roku, posiadali 206 woluminów ${ }^{43}$. We wrześniu 1820 roku w domu zakonnym księży misjonarzy (lazarystów) w Świętym Wojciechu koło Gdańska naliczono 787 woluminów ${ }^{44}$. Natomiast w klasztorze pojezuickim w Grudziądzu znaleziono 140 woluminów ${ }^{45}$. Warto także odnotować, że zachował się liczący kilkaset woluminów katalog biblioteki kolegium jezuickiego w Malborku z 1716 roku $^{46}$.

Wśród 124 skatalogowanych w Bibliotece Elbląskiej woluminów kadyńskich, zdecydowanie najwięcej dotyczy tematyki teologicznej i ascetycznej. Odnajdujemy w tej grupie dzieła autorów wczesnochrześcijańskich - św. Augustyna, św. Cypriana, św. Cyryla Jerozolimskiego, św. Cyryla Aleksanryjskiego, Orygenesa, Tertuliana, Dionizego Areopagity, św. Efrema Syryjskiego, św. Fulgencjusza z Ruspe, św. Hieronima, św. Benedykta z Nursji, ale także autorów późniejszych, przede wszystkim z okresu średniowiecza - św. Tomasza z Akwinu, św. Bernarda z Clairvaux, św. Bonawentury i św. Roberta Bellarmina. Do dzieł teologicznych należy też zaliczyć publikację polskiego bernardyna Idziego Smukalskiego Veritas Christianae Religionis oraz znane Confession ${ }^{47}$ kard. Stanisława Hozjusza, biskupa warmińskiego. Warto też odnotować dzieło jezuity związanego z konwentami w Malborku, Gdańsku i Toruniu, Marcina Kreysela ${ }^{48}$ (1658-1714), pt.

${ }^{38}$ Wbrew wcześniejszym ustaleniom Edmunda Piszcza, zachował się katalog książek z klasztoru w Łąkach. Por. APG, 10/3112, k. 1-19; Piszcz, Biblioteka klasztoru oo. reformatów w Łąkach na Pomorzu, s. 207-226.

${ }^{39}$ APG, 6/30.006, k. 8-30.

${ }^{40}$ APG, 6/30.006, k. 31-73.

${ }^{41}$ APG, 6/30.006, k. 123-129.

${ }^{42}$ APG, 6/30.006, k. 130-147.

${ }^{43}$ APG, 6/30.006, k. 2-7.

${ }^{44}$ APG, 6/30.006, k. 75-122.

${ }^{45}$ APG, 6/30.006, k. 148-161.

${ }^{46}$ APG, 6/30.005.

${ }^{47}$ S. Hozjusz, Chrześcijańskie wyznanie wiary katolickiej, w: Dzieła wybrane, t. 1, thum. J. Wojtkowski, Olsztyn 1999.

${ }^{48}$ Kreysel urodził się 24 września 1658 r. w Pradze w Czechach. Do zakonu jezuitów wstąpił 14 października 1679 r.w Krakowie. Święcenia kapłańskie otrzymał w 1689 r. w Krakowie. Profesor filozofii i matematyki w Toruniu w latach 1696-1698. Kaznodzieja niemiecki w Wałczu w 16901691, Międzyrzeczu 1692-1693, Malborku 1693-1694, 1703-1704 i 1712-1714, Gdańsku 16941696, 1700-1703, 1704-1707 i 1708-1712, Toruniu 1696-1698 i 1707-1708, Poznaniu 1698-1700. Autor kilku druków polemicznych. Zmarł 2 stycznia 1714 r. w Malborku. Por. Archiwum Archi- 
Das unfürsichtige mit seinen Lehr- und Glaubens-Sätzen die Heil. Schrift. Zachowały się cztery egzemplarze Biblii w języku łacińskim a także podręcznik egzegetyczny Florentyna Schillinga i konkordancja biblijna Hugo de Sancto Caro Sacrorum Bibliorum vulgatae editionis concordantiae. Wśród książek dotyczących historii na uwagę zasługują Annales Ecclesiastici Cezara Baroniusa a także związanego z diecezją warmińską ks. Jana Leo Historia Prussiae ${ }^{49}$. Z zakresu prawa kościelnego pozostała książka Jana Kery Decreta Sacrae Sedis Apostolicae oraz Mariana Ossowskiego Decreta Sacrae Sedis Apostolicae r Regularibus. Do libri medicinales zaliczyć należy podręcznik Henryka Kaspra Abela Wohlerfahrner Leib-Medicus. Z działu liturgicznego zachowało się Ordinarium et caeremoniale pro usu Fratrum Minorum Observantium i Breviarium Romanum, zaś $\mathrm{z}$ działu kaznodziejskiego Jana Baptista Massillona Predigten welche vor dem Könige in Frankreich Ludwig den Funfzehnten gehalten worden. Tylko jedna książka dotyczy zagadnień filozoficznych. Dzieło pt. Compendium unosyllogisticum totius summae S. Thomae Aquinatis, wydał dominikanin związany z Gdańskiem, Tomasz Szulc Prątnicki ${ }^{50}$.

Większość zidentyfikowanych książek kadyńskich pozwala określić miejsce ich wydania. Najwięcej woluminów wydrukowano w Kolonii (17 sztuk), Antwerpii (16) i Lionie (10). Po kilka książek wydano w Paryżu (7), Bazylei (5), Dylindze (4), Frankfurcie nad Menem (3), Moguncji (3), Lipsku (3), Wetzlar (2) i Ingolstadt (2). Po jednej książce pochodzi z Augsburga, Salzburga, Rzymu, Würzburga, Bassano koło Wenecji, Hagenau, Gissen, Wiednia, Norymbergi, Konstancji, Amsterdamu, Drezna, Brukseli, Wittenbergi, Douai koło Lille, Strassburga, Wenecji, Franeker w Holandii, Bolonii i Kempten. Ogółem kilkanaście książek wydano w drukarniach na terenie dawnej Rzeczypospolitej. Z Poznania pochodzi 6 sztuk woluminów, z Braniewa i Oliwy po 2 woluminy a po jednym z Wilna, Częstochowy, Lublina i Gdańska. Po jednej książce wydano także w Kołobrzegu i Wrocławiu.

Najstarszą książką w analizowanym zbiorze kadyńskim jest Lombardica historia Jakuba de Voragine, wydana w Norymberdze w $1501 \mathrm{roku}^{51}$, najmłodszą zaś Idziego Smukalskiego Veritas Christianae Religionis wydana w 1788 roku w Poznaniu. Ogółem z XVI wieku pochodzi 31 woluminów, z XVII wieku 54 woluminy zaś z XVIII wieku 39 woluminów.

Wpisy proweniencyjne zostały umieszczone w 71 woluminach kadyńskich. Niekiedy jest to zaledwie lakoniczna adnotacja o włączeniu książki do księgozbioru konwentu w Kadynach podana w formie: Conventus Cadinensis Patrum

diecezji Warmińskiej w Olsztynie, AB H 11, k. 72v-73; Encyklopedia wiedzy o jezuitach na ziemiach Polski i Litwy 1564-1995, red. L. Grzebień, Kraków 1996, s. 330; W. Zawadzki, Duchowieństwo katolickie oficjalatu pomezańskiego w latach 1525-1821, T. II, Stownik, Elbląg 2009, s. 342.

${ }^{49}$ Ks. Jan Leo, Dzieje Prus, tłum. J. Wojtkowski, Olsztyn 2008.

${ }^{50}$ E. Ozorowski, Szulc (Prątnicki, Schulz) Tomasz, w: Słownik Polskich Teologów Katolickich, t. 4, red. H. Wyczawski, Warszawa 1983, s. 286.

${ }^{51}$ W Muzeum Archologiczno-Historycznym w Elblągu przechowywane jest to samo dzieło, wydane w Bazylei w 1490 roku (sygn. ME/76/HS). Książka ta posiada wpis proweniencyjny: „Prof. Samuel Wolffins, Silesius". 
Barnardinorum lub Ad Bibliothecam Conventus Cadinensis. W książce autorstwa Gulielmo Burio, obok wpisu Bibliotheca Conventus Cadinensis, dodano także datę roczną: 1789. Natomiast Confession Stanisława Hozjusza (Hosius), poza informacją o własności kadyńskiej, posiada także wpis: Convent Braunsberg zugehörig. Książka ta została wydana w 1560 roku i należała przypuszczalnie do ostatnich franciszkanów braniewskich. W wymierającym konwencie, gdy przebywało w nim jeszcze dwóch franciszkanów, ojciec Szymon Neumeister i 80-letni brat Bernard, biskup Hozjusz osadził 8 stycznia 1565 roku przybyłych do Braniewa jezuitów. Franciszkanie braniewscy pozostawili jezuitom pokaźną bibliotekę, liczącą 300 woluminów. Choć większość tych książek w 1626 roku została zrabowana przez Szwedów, niektóre, jako mniej przydatne luteranom, zostały pozostawione przez okupanta w klasztorze. Jedna z nich trafiła z czasem do Kadyn ${ }^{52}$.

W książkach kadyńskich odnaleziono adnotacje proweniencyjne odnoszące się do kapłanów diecezjalnych, zakonników oraz osób świeckich. Ponadto w kilku woluminach znajdują się wpisy nieczytelne lub o nieustalonej treści, zapisane niekiedy w formie inicjałów.

Wśród właścicieli i darczyńców książek, włączonych do biblioteki bernardyńskiej w Kadynach, było 16 kapłanów diecezji warmińskiej: Józef Bohnek, Stanisław Bużeński, Antoni Joachim Ehlert, Michał Elsner, Jerzy Engelberg, Krystian Kazimierz Greiffenberg, Jerzy Heide, Józef Jakub Kretzmann, Teofil Ananiasz Meyer, Marcin Redlitz, Jan Reiter, Krzysztof Schmidt, Karol Schrader, Jan Schwahn, Zachariasz Jan Szolc, Szymon Wagner.

Najwięcej, 14 woluminów, przekazał bernardynom ich sąsiad, proboszcz tolkmicki, ks. Jan Schwahn. Urodził się w 1696 roku w Braniewie. Od 1706 roku kształcił się w gimnazjum braniewskim. W latach 1720-1733 był wikariuszem i kaznodzieją niemieckim w kościele św. Mikołaja w Elblągu. W 1733 roku został komendariuszem, a w 1736 roku proboszczem w Tolkmicku. Zmarł 5 maja 1773 roku w Tolkmicku. Książki ze swej biblioteki przekazywał bernardynom kadyńskim kilkakrotnie: dnia 6 stycznia, 4 marca, 24 marca i 27 marca 1737 roku, 31 grudnia 1739 roku oraz w latach 1740 i 1742, o czym informują wpisy w niektórych woluminach. Były to książki niemal wyłącznie o treści teologicznej ${ }^{53}$.

Cztery woluminy kadyńskie były własnością dwóch wybitnych kanoników kapituły katedralnej we Fromborku, Stanisława Bużeńskiego i Zachariasza Jana Szolca.

Dzieła św. Cypriana i św. Fulgencjusza z Ruspe otrzymali bernardyni od Stanisława Bużeńskiego. Pochodził on z okolic Sieradza. Uzyskał doktorat Akademii Krakowskiej i był sekretarzem prymasa Leszczyńskiego. Członkiem kapituły warmińskiej został 15 kwietnia 1664 roku. Był także kanonikiem gnieźnieńskim, krakowskim i archidiakonem gnieźnieńskim. W 1683 roku otrzymał prawo czytania książek heretyckich. W 1689 roku został mianowany wikariuszem generalnym. Swoją bogatą bibliotekę przekazał uniwersytetowi krakowskiemu i gimnazjum jezuickiemu w Braniewie, a pojedyncze egzemplarze jego książek znalazły się w Kadynach. Zmarł 5 kwietnia 1692 roku $^{54}$.

${ }^{52}$ A. Szorc, Braniewo, Olsztyn 1995, s. 153-154.

${ }^{53}$ M. Józefczyk, Elbląskie duchowieństwo katolickie na tle dziejów miasta 1246-1945, Elbląg 2005, s. 257.

${ }^{54}$ A. Kopiczko, Duchowieństwo katolickie diecezji warmińskiej w latach 1525-1821, Tom 2. Stownik, Olsztyn 2000, s. 41-42. 
Zachariasz Jan Szolc przekazał zakonnikom księgi liturgiczne, Graduale Romanum i Antiphonarium Romanum. Urodził się w 1630 roku w warmińskiej rodzinie mieszczańskiej. Był doktorem Akademii Krakowskiej. Studiował także w Padwie i Rzymie. W 1660 roku został kanonikiem dobromiejskim, a 8 maja 1665 roku kanonikiem katedralnym fromborskim. W latach 1681-1688 był wikariuszem generalnym i oficjałem. $Z$ ramienia biskupa był opiekunem klasztoru bernardynów w Barczewie. Zmarł 2 marca 1692 roku $^{55}$.

Własnością Krystiana Kazimierza Greiffenberga było dzieło Abrahama à s. Clara Nova et magna grammatica religiosa oraz Emanuela Lustianusa Rodrigueza Summa casuum conscientiae. W książce Rodrigueza zapisano informację, że Greiffenberg został jej właścicielem 29 maja 1714 roku. Kapłan ten urodził się około 1675 roku w Dobrym Mieście. Kształcił się w Alumnacie Papieskim w Braniewie a święcenia kapłańskie otrzymał w lutym 1700 roku w Lidzbarku Warmińskim. Był wikariuszem w Sątopach, Kiwitach i Lidzbarku Warmińskim. Od 1712 roku był proboszczem w Rogóżu, gdzie zmarł w 1734 lub 1735 roku. Zapis proweniencyjny w jego książce zaopatrzony jest datą roczną: $1730^{56}$.

Egzemplarz Biblii wydanej w Lionie w 1618 roku został przekazany przez księdza Jana Reitera najpierw do konwentu bernardyńskiego w Barczewie, a stamtąd trafił po pewnym czasie do Kadyn. Niewiele wiadomo o właścicielu Biblii. Urodził się około 1617 roku. Około 1640 roku rozpoczął naukę w gimnazjum reszelskim. Uzyskał doktorat z teologii. Był proboszczem w Orzechowie, Jesionowie, a w 1666 roku w Wapniku. Zmarł 15 stycznia 1677 roku. Bernardyni barczewscy wpisali go do katalogu dobroczyńców konwentu ${ }^{57}$.

Ksiądz Michał Hieronim Elsner (Ölsner) był właścicielem Disquisitionum magicarum libri sex autorstwa Martina Antonio del Rio. Elsner urodził się w Skolitach około 1655 roku. Od 1677 roku kształcił się w Alumnacie Papieskim w Braniewie. Prezbiterat otrzymał 6 października 1681 roku. Pracował jako duszpasterz w Lechowie i Krośnie. W latach 1691-1701 był wikariuszem w Elblągu. Losy jego po 1701 roku są nieznane ${ }^{58}$. Obok Elsnera w tej samej książce znajduje się nazwisko innego kapłana, niestety nieczytelne. Możliwy odczyt to: Antoni Elsch lub Foch. Nie było jednak wśród duchownych warmińskich kapłana o tym nazwisku.

Trzy książki autorstwa Louis Ellies Dupina przekazał w 1781 roku do Kadyn Józef Ksawery Bohnek (Borneck). Dwie z nich należały wcześniej do innego warmińskiego kapłana Jerzego Alberta Heide. Ksiądz Heide urodził się w 1705 roku w Praslitach koło Dobrego Miasta w rodzinie chłopskiej. Od 1724 roku kształcił się w Alumnacie Papieskim w Braniewie. Święcenia kapłańskie otrzymał 2 czerwca 1729 roku we Fromborku. Był wikariuszem w Braniewie. W 1737 roku został

${ }^{55}$ A. Kopiczko, Szolc (Scholz) Zachariasz Jan, w: Stownik biograficzny kapituly warmińskiej, red. J. Guzowski, Olsztyn 1996, s. 247.

${ }^{56}$ Kopiczko, Duchowieństwo katolickie diecezji warmińskiej w latach 1525-1821, s. 99.

57 W. Koppenhagen, Die Totentafel des ehemaligen Franziskanerklosters zu Wartenburg, w: „Zeitschrift für die Geschichte und Altertumskunde Ermlands”, 23 (1929) s. 155; Kopiczko, Duchowieństwo katolickie diecezji warmińskiej w latach 1525-1821, s. 267.

${ }^{58}$ Józefczyk, Elbląskie duchowieństwo katolickie, s. 249. 
proboszczem w Grzędzie a w 1745 roku w Kwiecewie. Od 1754 roku był archiprezbiterem w Lidzbarku Warmińskim, gdzie zmarł w 1765 roku. Natomiast Józef Ksawery Bohnek urodził się w 1729 roku w Dobrym Mieście. Do kapłaństwa przygotowywał się w Braniewie. Prezbiterat otrzymał 28 października 1753 roku. Pracował jako wikariusz w Radostowie i Lidzbarku Warmińskim. Od 1768 roku był proboszczem w Bisztynku, a od 1770 roku archiprezbiterem w Jezioranach. Tam zmarł 29 lutego 1801 roku. Z biogramów obu księży wynika, że współpracowali ze sobą w Lidzbarku Warmińskim i tam zapewne Bohnek wszedł w posiadanie książek po proboszczu Heide. Potem zaś, przez pośrednictwo zaprzyjaźnionego bernardyna Cyriaka Kelcha, książki trafiły do Kadyn ${ }^{59}$.

Dwie adnotacje proweniencyjne duchownych warmińskich znajdują się także w konkordancji biblijnej Hugo de Sancto Caro. Pierwszym właścicielem, wydanej w 1714 roku książki, był wikariusz katedralny we Fromborku Józef Kretzmann. Funkcję tę pełnił w latach 1725-1729. W 1729 roku został proboszczem w Piotrowcu, a w 1748 roku beneficjantem przy szpitalu św. Anny we Fromborku. Zmarł 26 maja 1756 roku we Fromborku. Adnotacja w książce potwierdza, że w 1731 roku jej właścicielem był już inny duchowny warmiński, Antoni Joachim Ehlert. Był kapłanem w Tolkmicku. W 1716 roku został wikariuszem katedralnym we Fromborku, a w 1722 roku komendariuszem w Błudowie. Od 1727 roku do śmierci, która nastąpiła 28 marca 1738 roku, był proboszczem w Tolkowcu. W 1742 roku książka trafiła do biblioteki kadyńskiej ${ }^{60}$.

Własnością księdza Karola Schradera był inkunabuł Summa angelica de casibus conscientiae, cum additione Hieronymi Tornieli wydany w Norymberdze w 1498 roku oraz starodruk autorstwa papieża Leona I Opera D. Leonis Magni drukowany w Antwerpii w 1583 roku. Schrader urodził się w 1699 roku we Fromborku. W 1716 roku kształcił się w seminarium diecezjalnym w Braniewie. W 1722 roku był wikariuszem katedralnym we Fromborku, w 1738 roku komendariuszem w Błudowie. W 1746 roku był proboszczem w Lechowie, gdzie zmarł w marcu 1752 roku. Schrader przekazał starodruk do biblioteki kadyńskiej w kwietniu 1742 roku. Natomiast w inkunabule przy jego nazwisku umieszczona jest data 26 listopada 1726 roku $^{61}$.

Dzieło św. Tomasza z Akwinu Summa casuum conscientiae ad curam animarum w 1696 roku zostało przekazane do Kadyn przez Teofila Ananiasza Meyera (Meiera). Właściciel książki urodził się w 1643 roku na Pomorzu. Początkowo był luteraninem i profesorem filozofii w Królewcu. Dnia 15 września 1685 roku przeszedł na katolicyzm i w tym samym roku wstąpił do Alumnatu Papieskiego w Braniewie. Po święceniach kapłańskich w 1688 roku (lub 1687) został kapelanem beneficjum Świętej Trójcy w Braniewie. Uprawiał teologię kontrreformacyjną. Wśród zachowanych książek kadyńskich zachowało się jego dzieło Das sandgründige Lutherthumb, dass ist, ein klarer Beweiss, wydane w Oliwie w 1695 roku. Zmarł w 1705 roku $^{62}$.

\footnotetext{
${ }^{59}$ Kopiczko, Duchowieństwo katolickie diecezji warmińskiej w latach 1525-1821, s. 31, 112.

${ }^{60}$ Tamże, s. 172.

${ }^{61}$ Tamże, s. 289-290.

${ }^{62}$ Tamże, s. 219-220.
} 
W bibliotece seminaryjnej w Olsztynie znajduje się starodruk Clingiusa Conradusa De securitate conscientiae Catholicorum in rebus Fidei z 1563 roku, który zanim trafił do Kadyn, był własnością dwóch księży warmińskich, Krzysztofa Schmidta i Jerzego Engelberga (Engelbrechta). Krzysztof Schmidt pochodził z Braniewa. W 1571 roku studiował teologię w Lipsku, a jesienią 1572 roku powrócił na Warmię. W 1574 roku był wikariuszem w Braniewie, a w latach 15831590 proboszczem w Kwiecewie. Dnia 17 października 1591 roku otrzymał kanonię dobromiejską. Zmarł w 1605 roku w Dobrym Mieście. Drugi kapłan, Jerzy Engelberg, urodził się około 1570 roku w Podleśnej koło Dobrego Miasta. Od 22 lutego 1594 roku kształcił się w seminarium braniewskim. Prezbiterat otrzymał 6 marca 1599 roku. Był wikariuszem w Lidzbarku Warmińskim, a w latach 16021609 wikariuszem w Glotowie. W latach 1612-1649 był proboszczem w Orzechowie, gdzie zapewne zmarł. Obaj duchowni byli więc związani z Dobrym Miastem i pobliską parafią w Glotowie i zapewne znali się osobiście. W książce znajduje się informacja, że Schmidt był jej właścicielem w 1593 roku, następnie przekazał ją P. Busau ${ }^{63}$, a ten w 1603 roku oddał ją swemu przyjacielowi Jerzemu Engelbergowi. Dnia 27 czerwca 1691 roku starodruk był już w posiadaniu bernardynów kadyńskich $^{64}$.

Inny starodruk przechowywany obecnie w bibliotece seminaryjnej w Olsztynie, Guillermusa Parisiensis, Postilla super Evangelia de tempore et de sanctis, był niegdyś własnością ks. Marcina Redlitza. Bardzo mało o nim wiadomo. W 1625 roku był wikariuszem katedralnym we Fromborku. Natomiast w 1630 roku był proboszczem w Długoborze, gdzie zmarł w 1671 roku. Datę zgonu odnotowano także w starodruku ${ }^{65}$.

Ostatni spośród księży warmińskich, Szymon Wagner wymieniony został w Antiphonarium Romanum de tempore et sanctis z 1634 roku. Naukę rozpoczął w gimnazjum reszelskim w 1656 roku. Wikariuszem w Elblągu był w 1668 roku, a w 1670 roku we Fromborku, w 1671 roku komendariuszem w Błudowie i archiprezbiterem we Fromborku. W 1579 roku został archiprezbiterem w Pieniężnie, gdzie zmarł 31 października 1688 roku $^{66}$.

Analiza zapisów proweniencyjnych odnoszących się do duchowieństwa warmińskiego wskazuje, że większość z księży związana była duszpastersko z północną i środkową Warmią. Niektórzy duchowni żyli w niewielkiej odległości od Kadyn, w Braniewie i najbliższej okolicy, a to sprzyjało pozyskiwaniu książek przez tamtejszy konwent bernardyński.

W inkunabule Sermones de tempore et de Sanctis odnotowano Mikołaja Swichtenbergk, który tę książkę podarował franciszkanom w Barczewie. Urodził się około 1435 roku w Gdańsku. Od 1462 roku studiował w Bolonii. Święcenia kapłańskie otrzymał 8 maja 1468 roku. Posiadał beneficjum wikariuszowskie przy kościele Panny Maryi w Gdańsku. Był proboszczem kościoła pw. św. Jana w Gdańsku w latach 1479-1516, oficjałem gdańskim w latach 1498-1516 oraz

\footnotetext{
${ }^{63}$ Osoba niezidentyfikowana. Być może był to zakonnik - Pater Busau?

${ }^{64}$ Kopiczko, Duchowieństwo katolickie diecezji warmińskiej w latach 1525-1821, s. 65, 287.

${ }^{65}$ Tamże, s. 264.

${ }^{66}$ Józefczyk, Elbląskie duchowieństwo katolickie, s. 246
} 
archidiakonatu pomorskiego w latach 1498-1516. Ponadto opiekował się biblioteką przy kościele Panny Maryi w Gdańsku. Był wybitnym bibliotekarzem i bibliofilem pomorskim. Ofiarodawca zmarł 26 czerwca 1518 roku w Gdańsku i został pochowany w kościele św. Jana ${ }^{67}$.

Jedna z książek kadyńskich, Justusa Lipsiusa Admiranda sive de magnitudine Romana, należała wcześniej do kapłana diecezji chełmińskiej Bartłomieja Paneci (Paneaus, Panetij). Duchowny ten pochodził z Mielca. Dnia 13 maja 1594 roku przyjęty został do Akademii Krakowskiej. Proboszczem w Zwierznie był w latach 1612-1616, a w latach 1616-1625 archiprezbiterem w Chełmnie. Zapis w tej samej książce informuje, że w 1623 roku należała ona do księgozbioru rezydencji jezuickiej w Chojnicach ${ }^{68}$.

Nie ma natomiast pewności, czy wymieniony w dwóch woluminach dzieła św. Augustyna, Szymon Weiss z Torunia (Simonis Weiß Thoruniensis), jest tożsamy z ks. Szymonem Fryderykiem Weissem. Kapłan ten urodził się w 1636 roku w Radostowie na Warmii. Do kapłaństwa przygotowywał się w seminarium braniewskim, ale pierwsze lata posługi duszpasterskiej związał $\mathrm{z}$ oficjalatem pomezańskim w diecezji chełmińskiej. W latach 1668-1675 był wikariuszem w Cyganku, a w 1674 roku dodatkowo także komendariuszem w Nowym Stawie. W 1681 roku powrócił na Warmię, gdzie został proboszczem w Świątkach. Tam zmarł. Nie ustalono dotąd, gdzie kapłan ten przebywał w latach 1675-1681. Nie można więc wykluczyć, że został skierowany do pracy duszpasterskiej właśnie w Toruniu ${ }^{69}$.

Niejasna jest także proweniencja trzech tomów dzieła Franciszka Rzepnickiego Vitae praesulum Poloniae. Odnotowano tam z datą roczną 1782 duchownego A. Sampławskiego. Nazwisko to nie występuje wśród księży diecezji warmińskiej, było natomiast bardzo popularne w ziemi chełmińskiej. Być może więc właścicielem książki był ksiądz Aleksander Maciej Sampławski, herbu Korczak. W 1734 roku był proboszczem i dziekanem wąbrzeskim. W 1748 roku został kanonikiem chełmińskim. W 1773 roku zrezygnował z kanonii i probostwa z powodu podeszłego wieku. Żył jeszcze w 1778 roku. Jest bardzo prawdopodobne, że książki trafiły do Kadyn poprzez zapis testamentalny Sampławskiego ${ }^{70}$.

Siedem woluminów dzieła Jeana Baptiste Massillona Predigten welche vor dem Könige in Frankreich Ludwig den Funfzehnten gehalten worden, zaopatrzono w jednakowy ekslibris. Książki te należały do księgozbioru księdza Amanda de Schwemersdorff. Urodził się w 1712 roku. W latach 1750-1752 duchowny ten był proboszczem parafii Zwrócona $\mathrm{w}$ archiprezbiteracie ząbkowickim. W latach

${ }^{67}$ P. Czapiewski, Wykaz oficyałów gdańskich i pomorskich od 1467-1824 r., „Roczniki Towarzystwa Naukowego w Toruniu 1912”, t. 19, s. 14-17; Z. Nowak, Schwichtenberg Mikołaj, w: Słownik Biograficzny Pomorza Nadwiślańskiego, T. IV, red. Z. Nowak, Gdańsk 1997, s. 185186.

${ }^{68}$ Zawadzki, Duchowieństwo katolickie oficjalatu pomezańskiego $w$ latach 1525-1821, T. II, Stownik, s. 184.

69 Tamże, s. 261.

${ }^{70}$ A. Mańkowski, Prałaci i kanonicy katedralni chełmińscy od założenia kapituly do naszych czasów, Toruń 1928, s. 186-187. 
1750-1766 był kanonikiem kolegiaty św. Jakuba i Mikołaja w Nysie. W latach 1759-1766 był dziekanem kapituły kolegiackiej, a w latach 1765-1766 asesorem sądu biskupiego. Nie wiadomo jaką drogą książki ze Śląska trafiły do Kadyn ${ }^{71}$.

W wielu książkach kadyńskich pojawiają się imiona i nazwiska zakonników, najczęściej franciszkanów bernardynów. Trudno w tym przypadku mówić o właścicielach książek, bo książki w klasztorze stanowiły własność wspólną, ale wpisy te poświadczają z reguły fakt pozyskania książki przez konkretnego zakonnika do klasztornej biblioteki.

Najczęściej, bo aż dziesięciokrotnie, pojawia się zapis proweniencyjny o. Cyriaka Kelcha. Urodził się około 1730 roku. Do zakonu bernardynów wstąpił około 1748 roku. Święcenia kapłańskie otrzymał 22 grudnia 1753 roku w katedrze chełmińskiej. Był lektorem w seminarium zakonnym, najpierw filozofii w Piotrkowie Trybunalskim (1756-1759), następnie teologii w Warszawie (1759-1761), w Toruniu (1761-1768) i w Poznaniu (1768-1770). W prowincji zakonnej wielkopolskiej sprawował urzędy: kustosza (1770-1773) oraz gwardiana w Toruniu (17761780) i w Kadynach (1783-1785). Za jego przełożeństwa konwent kadyński obchodził setną rocznicę istnienia. Był autorem opublikowanego w 1773 roku dzieła o Trzecim Zakonie św. Franciszka pt. Tertius Ordo Poenitentium. Zmarł 27 marca 1785 roku w Elblągu. Spoczywa w Kadynach. W książkach z jego wpisem pojawiają się trzy daty roczne: 1771,1781 i $1782^{72}$.

W dziele św. Augustyna Meditationes znajduje się informacja, że 2 sierpnia 1754 roku korzystał z niego ojciec Augustyn Andrea, bernardyn kadyński. Wiadomo o nim tylko to, że zmarł jako organista w Kadynach 16 marca 1762 roku i tam zapewne spoczywa ${ }^{73}$.

Równie mało wiemy o Hieronimie Rochellu, który w 1691 roku był wikariuszem w konwencie kadyńskim. Zmarł jako kaznodzieja 15 czerwca 1706 roku w Kadynach ${ }^{74}$. Informacja o nim znajduje się w starodruku Clingiusa Conradusa De securitate conscientiae Catholicorum in rebus Fidei, przechowywanym w bibliotece seminaryjnej w Olsztynie.

W książce Angeliusa Brinckmanna Theologia universa speculativa, moralis,

${ }^{71}$ Catalogus almae Dioecesis Wratislaviensis [...] Caroli Leopoldi Schattauer [...] Cancelistae labore compilatus, Wratislaviae MDCCL, s. 17, 26; Cataloguis Cleri almae Dioecesis Wratislaviensis [...] MDCCLII, s. 15, 26; Catalogus cleri almae dioecesis Wratislaviensis [...] Josephi Theodori Kassner [...] Cancellistae, labore compilatus et expensis imopressus 1765, s. 17; Catalogus cleri almae dioecesis Wratislaviensis [...] Josephi Theodori Kassner [...] Cancellistae, labore compilatus et expensis imopressus 1766, s. 17.

${ }^{72}$ Archiwum Diecezji Pelplińskiej, C 54a, s. 11; Archiwum Prowincji oo. Bernardynów w Krakowie (dalej: APBK), W-29, s. 481; W. Zawadzki, Dzieje klasztoru bernardyńskiego w Kadynach, s. 176.

${ }^{73}$ Daniel Andreae, urodził się w 1693 r. w Piszu (Johansburg?), uczeń gimnazjum braniewskiego w 1709 r. Być może jego rodzonym bratem był kapłan warmiński Bartłomiej Józef Andreae (1678-1719). Por. APBK, W-29, s. 453; Die Schüler des braunsberger Gymnasiums von 1694-1776, w: Monumenta Historiae Warmiensis, Lieferung 36, Bd XII, 1, hrsg. G. Lühr, Braunsberg 1932, nr 1196 (1709), s. 57; Kopiczko, Duchowieństwo katolickie diecezji warmińskiej w latach 1525-1821, T. 2. Stownik, s. 7; Zawadzki, Dzieje klasztoru bernardyńskiego w Kadynach, s. 171.

${ }^{74}$ APBK, W-29, s. 381. 
polemica pojawiają się nazwiska dwóch bernardynów, Edwarda Bloese i Floriana Wilanta. Pierwszy z nich urodził się w 1753 roku we Fromborku. Od 1755 roku kształcił się w gimnazjum braniewskim. Do grudnia 1770 roku przebywał w klasztorze kadyńskim. W latach 1770-1772 i 1778-1780 pomagał w parafii św. Mikołaja w Elblągu. Od stycznia 1773 roku był kanodzieją świątecznym w Kadynach. W 1783 roku pomagał duszpastersko w Miłoradzu na Żuławach Malborskich. Zmarł 17 listopada 1784 roku w Stoczku Warmińskim ${ }^{75}$. O drugim zakonniku, Florianie Wilant podano tylko informację, że po 1773 roku był prowincjałem bernardynów (minister provincialis).

Określenie minister provincialis znajdujemy też przy nazwisku o. Władysława Golbackiego, w dwóch tomach Relationis historicae semestralis vernalis continuatio autorstwa Jacoba Francusa. Golbacki otrzymał tonsurę i niższe święcenia 20 grudnia 1710 roku we Włocławku. Ustalono, że zakonnik ten przebywał także w Kadynach. W 1739 roku przygotowywał w tym konwencie do złożenia profesji zakonnej tercjarza brata Antoniego Kleyna. Zmarł 13 maja 1741 roku w klasztorze bernardyńskim w Świeciu ${ }^{76}$.

Inny prowincjał bernardynów, Jan Kapistran Szysiecki (Lubawczyk), przekazał do Kadyn dwie książki, Abrahama à s. Clara Judas der Ertz-Schelm für ehrliche Leuth oraz Ordinarium et caeremoniale pro usu Fratrum Minorum. Wpis proweniencyjny w pierwszej z wymienionych książek opatrzono datą 4 czerwca 1726 roku. Historiografia zakonna uważa Szysieckiego za najwybitniejszego bernardyna XVIII wieku. Urodził się około 1680 roku w Lubawie w rodzinie mieszczańskiej. Po święceniach kapłańskich uczył krótko teologii moralnej w Kościanie i rychło przeszedł do administracji zakonnej. W latach 1709-1713 był kustoszem poznańskim i kaznodzieją generalnym. W latach 1714-1716 był gwardianem w Świeciu, w 1720 roku gwardianem w Lubawie, a w 1722 roku ponownie kustoszem w Poznaniu. W latach 1725-1728 i 1734-1737 był prowincjałem bernardynów. Na tym urzędzie dbał o poziom dyscypliny zakonnej i wykształcenie zakoników. W 1728 roku został po raz trzeci kustoszem poznańskim oraz kustoszem prowincji. W 1729 roku brał udział w kapitule generalnej w Mediolanie, a w 1732 roku w kongregacji generalnej w Rzymie. W 1731 roku z ramienia Rzymu wizytował klasztor jasnogórski. Był wzorowym zakonnikiem i przełożonym. W klasztorach, którymi rządził, przeprowadzał daleko zakrojone prace remontowe. Przy licznych zajęciach miał czas na prace pisarskie. Dbał o biblioteki klasztorne. Zbiory biblioteki poznańskiej powiększył o ponad 380 tomów. Zmarł 14 kwietnia 1753 roku w Poznaniu ${ }^{77}$.

Kilka wpisów proweniencyjnych dotyczących bernardynów nie uzyskało po-

${ }^{75}$ APBK, W-29, s. 48; Józefczyk, Elbląskie duchowieństwo katolickie, s. 270.

${ }^{76}$ Archiwum Diecezji Włocławskiej, ASWłP 8 (98cz), k. 40v; APBK, W-29, s. 431; Zawadzki, Dzieje klasztoru bernardyńskiego w Kadynach, s. 174.

${ }^{77}$ W.F. Murawiec, Twórczość bernardynów o życiu wewnętrznym w 2. pot. XVI i w wieku XVII, w: Pięćset pięćdziesiąt lat obecności oo. bernardynów w Polsce (1453-2003), red. W.F. Murawiec, D.A. Muskus, Kalwaria Zebrzydowska 2006, s. 231, 232; E. Lenart, Biblioteki bernardyńskie w Polsce od 2. połowy XV wieku do końca wieku XVIII, s. 668; H.E. Wyczawski, Szysiecki (Lubawczyk) Jan Kapistran, w: Słownik Polskich Teologów Katolickich, t. 4, Warszawa 1983, s. 295-296. 
głębionej analizy. W dziele Martina Kreyssela odnotowano gwardiana Ludwika Votruha, który miał przejść na placówkę we Wschowej oraz prowincjała Jana Kamrowskiego. Niestety nie opatrzono wpisu żadną datą. Podobnie zresztą jak w książce Joannesa Kery, w której znalazło się nazwisko Kazimierza Sosnarskiego i prowincjała Mariana Gigniewskiego ${ }^{78}$. Natomiast przy informacji o Antonim Zarembie, w książce Filipa Bonanni, podano 1762 rok. W dziele zaś Ordinarium własnoręczny wpis umieścił wikariusz Stanisław Grodicius z datą 1694 rok. Przypuszczalnie bernardynem był też Stanisław Lipac[?], który przekazał dla konwentu w Barczewie Statuta, constitutiones et decreta generalia familiae Cismontanae.

Cztery woluminy zanim trafiły do Kadyn były w posiadaniu dominikanów poznańskich. Były to trzy tomy sumy teologicznej św. Tomasza z Akwinu oraz Opuscula Tomasza de Vio. W 1682 roku książki te były w posiadaniu dominikanina Jana Damazego Wójcickiego ${ }^{79}$ z klasztoru w Poznaniu. Wcześniej jednak, dnia 1 października 1603 roku, tymi książkami posługiwał się Paweł Slupsensis, o nieustalonej tożsamości. Nie wiadomo kiedy i w jaki sposób omawiane woluminy znalazły się w bibliotece kadyńskiej.

Własnością dominikanów był także pierwszy tom dzieł Tertuliana. W 1623 roku książka trafiła do konwentu przy kościele św. Mikołaja w Gdańsku, wcześniej zaś, w 1603 roku należała w Krakowie do niejakiego Bochwicza.

Dzieło ks. Jana Leo Historia Prussiae, podarował bernardynom rektor kolegium jezuitów w Braniewie, o. Michał Nahser (Nazart). Urodził się 12 sierpnia 1687 roku w Ramutkach na Warmii. Do zakonu jezuitów wstąpił 11 września 1707 roku w Wilnie. Był nauczycielem w szkołach: w Królewcu w latach 17171718, w Braniewie (1718-1720 retoryki, 1721-1723 filozofii), w Wilnie 17251728 (filozofii), w Warszawie 1723-1724 (teologii moralnej) oraz w Braniewie (1724-1725 prawa kanonicznego; 1728-1732 teologii scholastycznej). W latach 1724-1725 pełnił funkcję regensa seminarium diecezjalnego, a 1728-1731 seminarium papieskiego w Braniewie. Był rektor w Reszlu w latach 1732-1735, superiorem w Świętej Lipce 1735-1738 i 1754-1755, rektorem w Braniewie 17381744 i Łomży 1744-1754. Zmarł 10 stycznia 1758 roku w Braniewie. Z biogramu Nahsera wynika, że książka ks. Leo została przekazana do Kadyn pomiędzy 1738 a 1744 rokiem $^{80}$.

Najmniej wiadomości udało się uzyskać o osobach świeckich zapisanych w książkach kadyńskich. Niektóre odczyty są niepewne, inne zaś bardzo ogólne.

Interesujący wpis znajduje się w egzemplarzu katolickiej Biblii, wydanej w Antwerpii w 1603 roku. Książkę tę od królewny szwedzkiej Anny Wazówny (1568-1625), w 1621 roku miał otrzymać elblążanin Marcin Galli. Po nim zaś, Biblia była w posiadaniu Samuela Wernera, pisarza sądu ziemskiego w Elblągu od 1655 roku, który zmarł 13 listopada 1661 roku $^{81}$.

\footnotetext{
${ }^{78}$ Odczyt nazwiska niepewny.

${ }^{79}$ Wpis proweniencyjny został zamazany i odczyt nazwiska jest niepewny - Wuycisky, Wieysczycky, Wieschycky.

${ }^{80}$ Encyklopedia wiedzy o jezuitach na ziemiach Polski i Litwy 1564-1995, s. 449-450.

${ }^{81}$ To samo imię i nazwisko nosił organista kościoła NMP w Elblągu w latach 1686-1707. Por. K. Mikulski, Urzędnicy miejscy Elblaga w latach 1524-1772, Elbląg 2010, s. 236 (nr 1220); K.M.
} 
Nic nie wiadomo o postaci Krzysztofa Aryńskiego, Jana Baumgartnera ${ }^{82}$, Piotra B[?]cka, Pawła Kazimierza Gzowskiego ${ }^{83}$, Zygmunta Humielskiego, Franciszka Piekulij ${ }^{84}$, Benedykta Rebigij, Roberta Wardusa i Jana Weicherta. Kilka możliwych interpretacji pozostawia też wpis - Moses London w dziele Christiana Wolffa Anmerckungen über die vernüfftige Gedancken von Gott.

Wszystkie wpisy proweniencyjne sporządzono w języku łacińskim lub niemieckim. Jak wykazano, dotyczą one osób żyjących w okresie od XVI do XVIII wieku. Nie odnaleziono natomiast żadnego wpisu z XIX wieku, bo wówczas klasztor walczył o przetrwanie. Wprawdzie zdarzają się adnotacje świadczące o przekazywaniu do Kadyn większych zasobów bibliotecznych, jednak większość woluminów pozyskiwano przez długi okres czasu od przypadkowych osób. Jak już wspomniano, tak rodziło się większość księgozbiorów franciszkańskich, nie tylko w Prusach, ale i w innych częściach Rzeczypospolitej. Tak więc pod względem genezy, struktury i zawartości, bibliotekę bernardyńską w Kadynach należy uznać za porównywalną z bibliotekami w innych placówkach tej samej rodziny zakonnej.

Należy też pamiętać, że przechowywany w Bibliotece Elbląskiej zbiór ksiąg kadyńskich jest zaledwie niewielką częścią pierwotnego księgozbioru sprzed kasaty. Urzędnicy pruscy wybrali najcenniejsze i przypuszczalnie najstarsze książki i odesłali je do regencji gdańskiej. Jeśli nie zostały one przekazane w XIX wieku do Berlina, dziś mogą znajdować się w bibliotekach gdańskich. Zapewne stopniowo, wraz z inwentaryzacją księgozbioru biblioteki seminaryjnej w Olsztynie, ujawniane będą kolejne przechowywane tam książki kadyńskie. Największym wyzwaniem pozostaje jednak odnalezienie książek przewiezionych w 1830 roku do Królewca. Miasto to zostało w 1945 roku bardzo zniszczone, a potem na kilkadziesiąt lat zamknięte nie tylko dla turystów, ale i naukowców. Współcześnie jednak, nie bez trudności, kwerendziści odnajdują resztki dawnych królewieckich bibliotek $^{85}$. Być może ocalały wśród nich także książki bernardynów z Kadyn.

Kowalski, Kultura muzyczna, w: Historia Elblaga, Tom II, część 2 (1626-1772), Gdańsk 1997, s. 211.

${ }^{82}$ Przy jego nazwisku zapisano nazwę miasta - Magdeburg. Należy odnotowa też, że Jan Baumgart był sekretarzem sądów w Elblągu od 1669 r. Zmarł 7 sierpnia 1676 r. Por. Mikulski, Urzędnicy miejscy Elblaga, s. 231 (nr 1161).

${ }^{83}$ Odczyt nazwiska niepewny.

${ }^{84}$ Żył w XVIII wieku.

${ }^{85}$ J. Włodarski, Katalog zbiorów „Biblioteki Wallenrodzkiej” w muzeum Państwowego Rosyjskiego Uniwersytetu im. I. Kanta w Kaliningradzie, „Rocznik Elbląski”, 23 (2010) s. 197-256. 


\title{
ANEKS \\ Katalog książek klasztoru bernardyńskiego w Kadynach w zasobach Biblioteki Elbląskiej ${ }^{86}$
}

\author{
ABEL Henricus Caspar \\ Wohlerfahrner Leib-Medicus derer Studenten, welcher so wohl allen auf Schulen, \\ Gymnasiis und Universitaeten lebenden, oder auf Reisen begriffenen gelehr- \\ ten Personen, Leipzig, Friedrich Groschuff, 1713. $16^{\circ}$. \\ 1. kat. elbl.t. 2, s. 520 \\ 2. sygn. 92962 \\ 3. 5248 \\ 4. Ad usum P[at]ris Fr[atr]is Cyriaci Kelch L[ectori]J[ubilato] Anno 1782
}

\section{ABRAHAM à s. Clara}

Judas der Ertz-Schelm für ehrliche Leuth oder Eigentlicher Entwurff und Lebensbeschreibung des Iscariotischen Bößwicht, Dritte Teil, Saltzburg, Melchior Haan, 1692. $4^{\circ}$.

1. kat. elbl. t. 2 , s. 30

2. sygn. Ob.7.II.4454

3. 2134

4. Applico Conventui Cadinensi Ord[inis] Min[orum] Observ[antium] S. Francisci Anno D[omi]ni 1726 die 4 Juny, Frater Kapistranus Szysiecki, Minister Provincialis

\section{ABRAHAM à s. Clara}

Nova et magna grammatica religiosa, Colonia, Servatius Noethen, $1721.8^{\circ}$.

1. kat. elbl. t. 1 , s. 177

2. sygn. 219345

3. 7889

4. Christiani Casimiri Greiffenberg constat floreni 5 Anno 1730

\section{AD CASUS}

Ad casus conscientiae de mandato olim Eminentissimi et Reverendissimi Domini Domini Prosperi Lambertini S.R.E. Card. ac Bononiae Archiep. deinde Sanctissimi D.N. Papae Benedicti XIV, Appendix Prima, Augusta Vindelicorum, Matthaeus Rieger \& filii, $1766.8^{\circ}$.

Appendix Tertia, 1767

${ }^{86}$ Katalog przygotowała mgr Ewa Chlebus, dyplomowany konserwator zbiorów zabytkowych. Autor artykułu dokonał korekty zapisów proweniencyjnych. Katalog zawiera podstawowe dane bibliograficzne (autor, tytuł, miejsce wydania, drukarnia, rok wydania, rozmiar książki). Ponadto, w punkcie pierwszym podano odniesienie do Katalog der Stadtbibliothek zu Elbing, Bd. 1-2, bearb. L. Neubaur, Elbing 1893-1894. Punkt drugi podaje sygnaturę. Punkt trzeci podaje numer inwentarzowy. Punkt czwarty uwzględnia zapisy proweniencyjne. Dodany przy niektórych woluminach punkt piąty zawiera ewentualne uwagi. 
1. kat. elbl. t. 1 , s. 177

2. sygn. 93428,2 woluminy

3. 5714 (Tom I) i 5715 (Tom III)

4. Brak

\section{ALVISET Virginius}

Murenulae sacrae vestis sponsae regis aeterni vermiculatae, opus de privilegiis ordinum regularium, Campidonae, Rudolphus Dreher, 1679. $4^{\circ}$.

1. kat. elbl. t. 1, s. 74

2. sygn. Ob.7.II.3202

3. 2017

4. Conventui Cadinensi oblat[us] a Perill[ustro] A[dmodum]R[everendo] D[omi]no D[omi]no Joanne Schwahn Praeposito Tolkmittensi. Deo gratias 1742

5. Na wyklejce przedniej rękopiśmienny spis druków zawartych w woluminie.

\section{ANDREAS à Matre Dei}

Tractatus de privilegiis regularium in communi, Colonia Agrippina, Johannes

Wilhelm Friesse, $1681.4^{\circ}$.

1. kat. elbl. t. 1, s. 74

2. sygn. Pol.7.II.2065

3. 1591

4. Cessit Conventui Cadinensi gratia $\mathrm{P}$ [erillustris]A[dmodum]R[everendi] D[omini] Joannis Schwahn Praepo[siti] Tolkmit[tensis] Deo gra[ti]as.

\section{AUGUSTINUS Aurelius s.}

Confessionum libri tredecim, Antverpia, Ioannes Gymnicus, $1546.12^{\circ}$.

1. kat. elbl. t. 1, s. 99

2. sygn. Ob.6.I.214

3. 234

4. Brak

\section{AUGUSTINUS Aurelius s.}

Meditationes, Soliloquia et Manuale, Colonia Agrippina, Cornel ab Egmondt et sociorum, $1702.12^{\circ}$.

1. kat. elbl. t. 1 , s. 100

2. sygn. 92990

3. 5286

4. Ex Bibliotheca Cadinensi

Habet usum simplicem huius libelli Fr[ater] Augustinus Andreae Ord[inis]S[a ncti]P[atris] Franc[isci] Regul[aris] Observantiae Anno D[omi]ni 17542 Augusti

Qui post fata eius illo utetur sit memor mei ad altare Dei rogo vehementer 
AUGUSTINUS Aurelius s.

Primus tomus eximii patris inter summa latinae ecclesiae ornamenta ac lumina principis D. Aurelii Augustini Hipponensis episcopi, Basilea, Ambrosius et Aurelius Froben, $1569,2^{\circ}$.

1. kat. elbl. t. 1, s. 99

2. sygn. Ob.6.IV.191, 2 woluminy

3. 1393 (Tom I) i 1394 (Tom IV)

4. Proweniencja w tomie I:

Simonis Weiß Thoruniensis

Hic liber donat[us] est ad Bibliotheca[m] Cadinensem ab Illustro ac A[dmodum] R[evere]ndo D[omi]no Joanne Schwahn Praeposito Tolkmitensi AD 1737

Proweniencja w tomie IV:

Simonis Weiß Thorun.

Ex munificentia Illustris ac Adm[odum] Reverendi D[omi]ni Joannis Swahn hic liber donatus est ad Bibliothecam Cadinensem Anno 17374 Marty. Cui Deus reddat gratiam.

5. Na przedniej wyklejce tomu I wklejony miedzioryt z przedstawieniem św. Augustyna

\section{BAMBERGENSIS Andreas}

Andreae Abbatis Bambergensis de Vita S. Ottonis Babenbergensis ecclesiae episcopi ac Pomeranorum gentis apostoli libri quatuor, Colberga, Ludovicus Röderus, $1681.4^{\circ}$.

1. kat. elbl. t. 1, s. 56; E.XII,146

2. sygn. Pol.7.II.368

3. 1525

4. Brak

\section{BARONIUS Caesar}

Annales Ecclesiastici das ist Kirchen Historien, Mayntz, Balthasar Lippius, T. I 1600; T. II - 1601; T. III - 1602. $4^{\circ}$.

1. kat. elbl. t. 1, s. 52

2. sygn. Ob.6.II.3895, 3 woluminy

3. 830 (Tom I), 831 (Tom II), 832 (Tom III)

4. Proweniencja w tomach I-III:

Hic liber cessit Bibliothecae Cadinensi ex gratia P[erillustris]D[omi]ni Swahn Praepositi Tolkmit[tensis] Deo gra[ti]as 1740

\section{BARONIUS Caesar}

Annales ecclesiastici, Colonia Agrippina, Antonius Hierati, sub signo Gryphi, T. I

- 1624; T. II-XII - 1685. $2^{\circ}$.

1. kat. elbl. t. 1 , s. 52

2. sygn. Ob.7.IV.297, 4 woluminy

3. 2493 (Tom I), 2494 (Tom IV), 2495 (Tom VII), 2496 (Tom X)

4. Brak 


\section{BARONIUS Caesar}

Martyrologium Romanum, Moguntia, Ioannes Theobald Schönwetter, 1631. $4^{\circ}$.

1. kat. elbl. t. 1 , s. 82

2. sygn. Ob.7.II.6960

3. 2245

4. Brak

5. Brak karty tytułowej.

\section{BARONIUS Caesar}

Sacrum Martyrologium Romanum ad novam Kalendarii rationem, \& Ecclesiasticae historiae veritatem restitutum, Colonia Agrippina, Ioannes Gymnicus, 1610. $4^{\circ}$.

1. kat. elbl. t. 1 , s. 82

2. sygn. Ob.7.II.2806

3. 1973

4. Martyrologium Romanum. Ego sum possesor huius libri Krzystofus Arinsky. Petrus B[?]ck. Martyris Confesoris.

\section{BARTHOLOMAEUS de Urbino}

D. Aurelii Augustini Milleloquium veritatis, Lugdunum, ad Salamandrae apud Senetorios fratres, $1555.2^{\circ}$.

1. kat. elbl. t. 1 , s. 100

2. sygn. Ob.6.IV.138

3. 1310

4. Brak

\section{BECHER Johann Joachim}

Chymischer Glücks-Hafen, oder Grosse Chymische Concordantz, Leipzig, Johann Paul Kraus, $1755.4^{\circ}$.

1. kat. elbl. t. 2, s. 487

2. sygn. 219009

3. 7530

4. Brak

\section{BELLARMIN Robert}

Chronologia brevis, ab orbe condito, usque ad annum Domini M.DC.LIV, Colonia Agrippina, Iodocus Kalcovius, $1654.8^{\circ}$.

1. kat. elbl., t. 1 , s. 257

2. sygn. Ob.7.II.4286a

3. 2124

4. Brak

\section{BELLARMIN Robert}

De scriptoribus ecclesiastiis, liber unus, Colonia Agrippina, Iodocus Kalcovius, 1657. $8^{\circ}$. 
1. kat. elbl. t. 1 , s. 98

2. sygn. Ob.7.II.4286

3. 2124

4. Brak

\section{BELLARMIN Robert}

Primi Tomi Secunda Controversia Generalis, De Christo Capite Totius Ecclesić,

Qvinque Libris Explicata, [s. 1.]: [s. n.], [s. a. - XVI w.], $8^{\circ}$.

1. kat. elbl. t. 1 , s. 156

2. sygn. Ob.6.II.3978

3. 911

4. Brak

\section{BENEDICTUS de Nursia}

Duodecim gradus humilitatis, Dilinga, Joannes Casparus Bencard, 1689, $12^{\circ}$.

1. kat. elbl. t. 1 , s. 194

2. sygn. Ob.7.I.667

3. 1801

4. Conven[tus] Cadinensis P[at]rum Barnardin[orum]

\section{BERNARDUS de Clairvaux}

Divi Bernardi Claraevallensis, Abbatis Primi, Religiosissimi Ecclesiae Doctoris, etc., Opera Omnia, Paris, [s. n.], 1602, $2^{\circ}$.

1. kat. elbl. t. 1 , s. 100

2. sygn. Ob.7.IV.196

3. 2476

4. Brak

\section{BIBLIA}

H KAINH $\triangle \mathrm{IA \Theta HKH} \mathrm{Novum} \mathrm{Testamentum.} \mathrm{Obscuriorum} \mathrm{vocum} \mathrm{\&} \mathrm{quorundam}$ loquendi generum accuratas partim suas partim aliorum interpretationes margini adscripsit Henricus Stephanus, [s. 1.]:[s. n.], 1604, $16^{\circ}$.

1. kat. elbl. t. 1 , s. 27

2. sygn. Ob.7.I.1094

3. 1849

4. Brak

\section{BIBLIA}

Biblia Sacra Vulgatae Editionis Sixti V. Pont. Max. Ivssv recognita atque edita, Antverpia, Officina Plantiniana, apud Ioannem Moretum, 1603, $2^{\circ}$.

1. kat. elbl. t. 1, s. 21

2. sygn. Ob.7.IV.197

3. 2477

4. Anna Regina. Sueciae. Gotorum. Vandalorum nec non magni ducatus Finlandiae heres virgo pyssima patrona ac benefectrix, Serenissima mea, donavit. 
$\mathrm{A}[\mathrm{nno}] \mathrm{D}$ [omini] 1621. Indigni sum Martini Galli. Elbing.

Sum pars Bibliothecae Samuelis Werneri

\section{BIBLIA}

Biblia Sacra, Vulgatae Editionis, Sixti V. Pont. Max. iussu recognita et Clementis VIII auctoritate edita, Lugdunum, Ioannes Iullieron, 1618, $8^{\circ}$.

1. kat. elbl. t. 1, s. 21

2. sygn. Ob.7.II.4645

3. 2144

4. Emptus Gedani Ao MDCXXV Mense Aug[usti] IHVH

Ex libris Joannis Reytis parochi nostri K[alksteinensis]

Ex Munificentia Adm[odum] R[evere]ndi D[omi]ni D[omini] Joannis Reytis Parochi Kelkstey[nensis] conventui Vartenburgensi applicatum. Orate pro eo. Nunc applicatum conventui Cadinensi F[ratrum] Minorum ad S[anctum] Antonium.

\section{BIBLIA}

Biblia Sacra, Vulgatae Editionis, [s. 1.]: [s. n.], [XVII w.], $8^{\circ}$.

1. kat. elbl. t. 1 , s. 21

2. sygn. Ob.7.II.7213

3. 2266

4. Brak

\section{BONANNI Filip}

Ordinum equestrium et militarium catalogus, Roma, Antonius de Rubeis, 1741. $4^{\circ}$.

1. kat. elbl. t. 1, s. 74

2. sygn. 95132

3. 7507

4. Librum hunc comparavit $\mathrm{P}$ [ater] Antonius Zaremba exercendo munus Agentis pro Provincia Maioris Poloniae S[anctae] Mariae Angelorum Anno 1762 Quem post Anno nempe 1782 cessit percharo suo convitio, mihi $\mathrm{P}$ [at]ri F[rat]ri Cyriaco Kelch L[ectori] Jubil[ato] ad usum simplicem July 23

\section{BONAVENTURA $s$.}

Distinctiones ex commentariis S. Bonaventurae in quattuor libros sententiarum collectae, Lutetia Parisiorum, Sebastian et Gabriel Cramoisy, 1646. $2^{\circ}$.

1. kat. elbl. t. 1, s. 101; E.XIII,251

2. sygn. Ob.7.III.649

3. 2306

4. Brak

BONAVENTURA $s$.

Opera omnia in tomos septem distributa, Lugdunum, Philippus Borde: Laurentius 
Arnaud: Petrus Borde, 1668, t. 1-7. $2^{\circ}$.

1. kat. elbl. t. 1, s. 100

2. sygn. Ob.7.IV.53, 7 woluminów

3. $2430,2431,2432,2433,2434,2435,2436$

4. Brak

\section{BONAVENTURA s.}

Speculum disciplinae ad novitios et de profectu religiosorum, Vilno, S.R.M. Academicis Societas Iesu, $1752,2^{\circ}$.

1. kat. elbl. t. 1, s. 101

2. sygn. Pol.8.I.2, Pol.8.I.2a, Pol.8.I.2b, 3 woluminy

3. 2504, 2505, 2506

4. Proweniencja w woluminie 2505:

Ad Bibliothecam Co[nven]t[us] Cadinensis

Proweniencja w woluminie 2506

Ad Refectorium Co[nven]t[us] Cadinensis. Conventus Cadinensis de S[ancti] Antoni de Padua

\section{BRANDIS Johann Eberhard}

Bene feliciterque morientium et mortuorum theatrum, novis concionibus funeralibus adornatum, Herbipolis, Job Hertz 1688. $4^{\circ}$.

1. kat. elbl. t. 1, s. 201

2. sygn. Ob.7.II.3204

3. 2017

4. Vide Alviset Virginius

\section{BREVIARIUM}

Breviarium Romanum ex decreto Sacrosancti Concillii Tridentini, [s. 1.], ex Duca-

li Campidonesi, Aloysius Galler, 1786. $8^{\circ}$.

1. kat. elbl. t. 1, s. 190

2. sygn. 219056

3. 7580

4. Brak

\section{BRINCKMANN Angelinus}

Controversiae Fidei Principaliores Sive in Materia Fidei Doctrina Acatholica, Doctrina Catholica, Obiectiones Acatholicae, Wetzlar, Nicolaus Ludovicus Winckler $1732.8^{\circ}$.

1. kat. elbl. t. 1 , s. 137

2. sygn. 93410

3. 5704

4. Brak

\section{BRINCKMANN Angelinus}

Theologia universa speculativa, moralis, polemica, Wetzlar, Nicolaus Ludovicus 
Winckler 1733. $8^{\circ}$.

1. kat. elbl.t. 1 , s. 137

2. sygn. 93409

3. 5704

4. Concedo Simplicem usum huius Libri M[ultum]V[enerabili]P[atri] Eduardo Bloese Pr[aedicatori] Festivali revocabiliter ad Conventum nostrum Cadinensem Anno D[omi]ni 1773

Fr[ater] Florianus Wilant Minister Provincialis manu propria

\section{BURIO Gulielmo}

Romanorum pontificum brevis notitia ritus ecclesiasticos, Bassano, Venetia apud Remondini, $1779.8^{\circ}$.

1. kat. elbl. t. 1 , s. 75

2. sygn. 93471

3. 5763

4. A[dmodum]R[everendi] P[at]ris Ciriaci Kelch manu propria

Bibliotheca Conventus Cadinensis 1789

\section{CONSTITUTIONES}

Constitutiones et decreta Apostolica a regularibus in publica Mensa, Posnaniae, ex typographia Clari Collegii Soc. Jesu, 1759. $8^{\circ}$.

1. kat. elbl. t. 1, s. 75; E. XIV, 385

2. sygn. 93431

3. 5722

4. Ad usum P[at]ris Fr[atr]is Cyriaci L[ectori] Jub[ilato] pro Bibliotheca Conventus Cadinensis ad S[anctum] Antonium Paduanum Anno 1771

Ad usum simplicem P[atr]ris Fr[atr]is Cyriaci Kelch L[ectori]J[ubilato] cum praesumpta licentia $\mathrm{A}$ [dmodum] $\mathrm{R}$ [everendi] $\mathrm{P}$ [at]ris $\mathrm{M}$ [inist]ri Pro[vincia]lis SDC referibiliter ad conventum eidem A[dmodum ]R[everendi] P[at]ri M[inist]ro bene visum

\section{CURIEUSES}

Curieuses Studenten-Bibliothecgen, worinnen gezeiget wird, was ein Studiosus Theologić, Juris, Medicinć, Philosophić und Politices, Leipzig, Friedrich Groschuff, $1718,12^{\circ}$.

1. kat. elbl. t. 1, s. 6

2. sygn. 92963

3. 5248

4. Vide Abel Henricus Caspar

\section{CYPRIANUS s.}

Opera Divi Caecilii Cypriani episcopi Carthaginensis, Basilea, officina Frobeniana, $1520.2^{\circ}$.

1. kat. elbl. t. 1,101

2. sygn. Ob.6.III.830 
3. 1094

4. Perillustris ac R[evere]ndus D[omi]nus D[omi]nus Stanislaus Buzynski Decanus Varmiensis Administrator et Cano[nicus] Gnes[nensis] Craco[viensis] Ep[iscopa]tus. Hunc librum Conventui Cadinensi Fratr[um] Min[orum] Obser[vantiae] obtulit.

5. Na karcie tytułowej zamalowane nagie postacie. Pomiędzy kartami bloku anonimowy list dotyczący działań wojennych z 16 czerwca 1684 roku.

\section{CYRILLUS Alexandrinus}

Divi Cyrilli, archiepiscopi Alexandrini, operum omnium, Tomus primus et secundus, Colonia, Melchior Novesianus, 1546, T. 1-2. $2^{\circ}$.

1. kat. elbl. t. 1, s. 101

2. sygn. Ob.6.III.930

3. 1172

4. M A G (znaczenie inicjałów nieustalone)

\section{CYRILLUS Hierosolymitanus}

TOY EN AГIOI $\Sigma$ ПАTPO

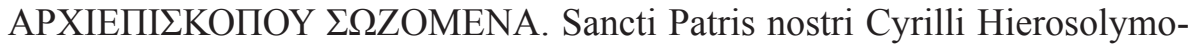
rum archiepiscopi opera, Lutetia Parisiorum, Dionysius Bechet, 1640. $2^{\circ}$.

1. kat. elbl. t. 1 , s. 101

2. sygn. Ob.7.III.940

3. 2372

4. Brak

\section{DEL Rio Martin [Antonio]}

Disquisitionum magicarum libri sex, Colonia Agrippina, Petrus Henning, 1633. $4^{\circ}$.

1. kat. elbl.t. 2, s. 552

2. sygn. Ob.7.III.700

3. 2319

4. Conventus Cadinensis

Sum Michaelis Hieronymi Ölsner [?] Adm[odum] R[everendo] D[omino] Antonio Elsch P.S.

\section{DIONYSIUS Areopagita}

Sancti Dionysii Areopatitae operum omnium quae extant, Tomus I-II, Lutetia Parisiorum, Petrus Chaudiere, $1644.2^{\circ}$.

1. kat. elbl. t. 1 , s. 101

2. sygn. Ob.7.IV.50

3. 2429

4. Brak

\section{DUPIN Louis Ellies}

Nova bibliotheca auctorum ecclesiasticorum eorum vitae historiam, Tomus pri- 
mus, Paris, sumpt. Societatis, 1692. $4^{\circ}$.

1. kat. elbl. t. 1 , s. 98

2. sygn. Ob.7.II.1689/1

3. 1886

4. Georgii [Heide]

Josephi Borneck C H manu propria Ex Cuius

Ex Cuius, plurimum suscipiendi, atque oppido Colendi viri, Illustris nempe Admodum Reverendi Domini Domini Josephi Xaverii Borneck Archipresbyteri Seeburgensis, parchari olim Condiscipuli, ac perpetuo aestimandi Mecaenatis, Gratia singulari, cepit hanc Bibliotheca nova mihi, magnopere multimodisque grato, Patri Fratri Cyriaco Kelch Ordinis Minorum de Observantia Lectori Theologiae arbitrio altioris superioritatis, determinandi cuiuspiam Conventus Bibliothecae, ceu Aurum Auro addenda, applicandare. Anno 1781.

\section{DUPIN Louis Ellies}

Nova bibliotheca auctorum ecclesiasticorum eorum vitae historiam, Tomus tertius, Colonia Agrippina, sumpt. Huguetanorum 1693. $4^{\circ}$.

1. kat. elbl. t. 1 , s. 98

2. sygn. Ob.7.II.1689/3, współoprawny z drukiem Ob.7.II.1690

3. 1887

4. Georgii Heide manu priopria post Josephi Borneck Ex Cujus

Ex Cuius impendio Colendi, Condiscipuli mei , Illustris Admodum Reverendi Domini Domini Josephi X. Borneck Archipresbyteri Seeburgensis Gratia singulari, cessit mihi, magnopere Grato, P[at]ri F[rat]ri Cyriaco Kelch Ordninis Minorum de Observantia Lectoris Jubilati arbitrio altioris Superioritatis Cuipiam Conventus determinandi Bibliothecae, ceu Aurum Auro, addenda applicandaque hanc Bibliotheca nova, Anno 1781.

\section{DUPIN Louis Ellies}

De antiqua ecclesiae disciplina dissertationes historicae, Colonia Agrippina, sumpt. Huguetanorum, 1691. $4^{\circ}$.

1. Brak

2. sygn. Ob.7.II.1690 współoprawny z drukiem Ob.7.II.1689/3

3. 1887

4. Ex gratia plurimum Colendi, Condiscipuli mei, Ill[ust]ris Adm[odum] R[evere]ndi D[omi]ni Josephi X. Borneck Archipresbyteri Seeburgensis, ad usum P[at]ris F[rat]ris Cyriaci Kelch Minoritae Observantiae Lectoris Jubilati pro Bibliotheca Conventus arbitrio Superioritatis Altioris determinandi.

\section{EPHREM Syrus s.}

Sancti Ephraem Syri, patris et scriptoris ecclesiae antiquissimi et dignissimi opera omnia, Colonia, Arnold Quentel, 1616. $2^{\circ}$.

1. kat. elbl. t. 1 , s. 102

2. sygn. Ob.7.III.680 
3. 2315

4. Ex gratia et munificentia Per[illustr]is Adm[odum] R[everendi] D[omi]ni $\mathrm{D}$ [omi]ni Joannis Schwahn Praepositi Tolkmitt[ensis] insignis Benefactoris Nostri hic liber cessit Bibliothecae Cadinen[si] ad S[anctum] Antonium Paduanum 1739 ultimo Decembris.

\section{ERASMUS Desiderius Roterdamus}

Ex recognitione, Basilea, Ioannes Froben, 1518. $2^{\circ}$.

1. kat. elbl. t. 2, s. 216

2. sygn. Ob.6.III.942

3. 1183

4. Brak

\section{FRANCUS Jacobus}

Relationis historicae semestralis vernalis continuatio, Jacobi Franci Historische

Beschreibung der denckwürdigsten Geschichten, So sich in Hoch- und Nieder-Teutschland, Franckfurt am Mayn, Engelhardische Erben und Johann Balthasar Graupitz, z. 1-11, 1701-1715. $4^{\circ}$.

1. kat. elbl. t. 1., s. 302 ; E.XXII,278

2. sygn. Pol.8.II.729, 2 woluminy

3. 2589 i 2590

4. Proweniencja w 2589:

Totum volumen Germanicum ab anno 1700 consistens in duodecim libris Historicis applico Conventui Cadinensi ad S[anctum] Antonium Paduanum. Fr[ater] Ladislaus M[iniste]r Pr[ovincia]lis manu propria

Ad Conventum Cadinensem Fr[ater] Ladislaus M[iniste]r Pr[ovincia]lis manu propria

Proweniencja w 2590:

Ad Conventum Cadinensem Fr[ater] Ladislaus Golbacki M[iniste]r $\operatorname{Pr}[$ ovincia]lis manu propria

\section{FULGENTIUS}

Opera B. Fulgentii Aphri, Episcopi Ruspensis [...] item opera Maxentii Iohannis

Servi Dei, Hagenau, Thomas Anselm, 1520. $2^{\circ}$.

1. kat. elbl. t. 1, s. 102

2. sygn. Ob.6.III.831

3. 1094

4. Perillustris ac R[evere]ndus D[omi]nus D[omi]nus Stanislaus Buzynski Decanus Varmiensis Administrator et Cano[nicus] Gnes[nensis] Craco[viensis] Ep[iscopa]tus. Hunc librum Conventui Cadinensi Fratr[um] Min[orum] Obser[vantiae] obtulit.

5. Na karcie tytułowej zamalowane nagie postacie. Pomiędzy kartami bloku anonimowy list dotyczący działań wojennych z 16 czerwca 1684 roku. 


\section{GRETSER Jacob}

Institutionum linguae grecae, Ingolstad, Adam Sartor, 1615. $8^{\circ}$.

1. kat. elbl. t. 1 , s. 143

2. sygn. Ob.7.II.2754

3. 1962

4. Joannes Weichert Anno Domini 16[?]

Conventus Cadinensis P[atrum] Bernardinorum AAJ

5. Uszkodzenie karty tytułowej.

\section{HELVICUS Christophorus}

Vindicatio locorum potissimorum, Gissa, Caspar Chemlin, $1620.8^{\circ}$.

1. kat. elbl.t. 1 , s. 160

2. sygn. Pol.7.II.5721

3. 1633

4. Brak

5. Rękopiśmienny indeks na karcie ochronnej.

\section{HERTZIG Franciscus}

Manuale controversisticum seu methodus compendiosa veritatem Fidei Catholicae, Wratislavia, Academicis Collegii Societatis Jesu, 1732. $8^{\circ}$.

1. kat. elbl. t. 1 , s. 160

2. sygn. Pol.8.II.79

3. 2527

4. Brak

\section{HIERONYMUS s.}

Lucubrationes omnes una cum pseudoepigraphis, Basilea, Ioannes Froben, 15241526. $2^{\circ}$.

1. kat. elbl. t. 1 , s. 103

2. sygn. Ob.6.IV.168, 4 woluminy: Tom I-III; IV+ indeks; V; VIII-IX

3. 1348 (Tom I-III), 1349 (Tom IV), 1350 (Tom V), 1351 (Tom VIII-IX)

4. Proweniencja w 1348:

Robertus Wardus. Domin[e] Jesu miserere mei.

Ex munificentia Illustris ac Adm[odum] Reverendi D[omi]ni Swahn Praepositi Tolkmittensis donatus est hic liber ad Bibliothecam Cadinensem Anno 173727 Marty. Cui Deus reddat gratiam.

Proweniencja w 1349:

Hic liber donatus ac Illustri Adm[odum] R[evere]ndo D[omi]no Joanni Swahn Praeposito Tolkmittensis ad Bibliothecam Cadinensem. Cui Deus sit ipsa merces. Ano 173724 Martii

Proweniencja w 1350:

Hic liber donatus ac Illustri ac Adm[odum] R[evere]ndo D[omi]no Joanne Swahn Praeposito Tolkmittensi ad Bibliothecam Cadinensem 173724 Martii. Deus sit illi merces.

Proweniencja w 1351: 
R. Warde

Ex munificentia Illustris ac Admodum Reverendi Domini Joannis Swahn Praepositi Tolkmittensis hic liber donatus est ad Bibliothecam Cadinensem. Anno 173724 Martii. Cui Deus sit ipse merces.

\section{HIERONYMUS $s$.}

Opera omnia, Francofurt ad Moenum und Lipsiae, Christian Gensch, 1684. $2^{\circ}$.

1. kat. elbl. t. 1 , s. 103

2. sygn. Ob.7.IV.112, 3 woluminy: Tom I-IV, V-VIII, IX-XI

3. 2454 (Tom I-IV), 2455 (Tom V-VIII), 2456 (Tom IX-XI)

4. Brak

\section{HOSIUS Stanislaus}

Confession, das ist ein Christliche Bekantnuß, Ingolstat, Alexander und Samuel Weyssenhorn, $1560.2^{\circ}$.

1. kat. elbl. t. 1, s. 115; E.XVIII.282

2. sygn. Pol.6.III.160

3. 195

4. Conventus Cadinensis Ord[inis] Min[orum] Observantium

Convent Braunsberg zugehörig

\section{HUGO de Sancto Caro}

Sacrorum Bibliorum vulgatae editionis concordantiae, Vienna, Martin Endter, 1714. $4^{\circ}$.

1. kat. elbl. t. 1, s. 47

2. sygn. 93978

3. 6498

4. Ex libris Antony Joachimi Elert Parochi Tolksdorffensis per commutationem Kyblery 1731

Ex libris Josephi Kreczmann Vicarius Cathedralis floreni 15

Post fata Clarissimi Adm[odum] R[everen]di D[omi]ni Antony Joachimi Elert Parochi Tolksdorffensis cessit praesens liber Conventui Cadinensi Anno 1742. Requiescat in pace et oretis pro anima eius

\section{HUGO Hermann}

Pia desideria libri III, Antverpia, Hieronim Verdussi, 1628. $8^{\circ}$.

1. kat. elbl.t. 1 , s. 195

2. sygn. Ob.7.II.5900

3. 2212

4. Conventus Cadinensis Ad S[anctum] Antonium Ord[inis] Minor[um] Reg[ularium] Obser[vantium]

5. Dopiski rękopiśmienne na wyklejkach. Książka naprawiana.

\section{HUNNAEUS August}

Brevissimus catechismus catholicus, Lugdunum, Stephan Michael, 1588. $2^{\circ}$. 
1. kat. elbl. t. 1, s. 131

2. sygn. Ob.6.IV.144/4d

3. 1320

4. Brak

\section{HUNNAEUS August}

De sacramentis Ecclesiae Christi axiomata, Lugdunum, Stephan Michael, 1588. $2^{\circ}$.

1. kat. elbl. t. 1 , s. 143

2. sygn. Ob.6.IV.144/4c

3. 1320

4. Brak

\section{IACOBUS de Voragine}

Lombartica historia, Nürnberg, Anthonius Koberger, 1501. $2^{\circ}$.

1. kat. elbl. t. 1, s. 82

2. sygn. Ob.6.III.691

3. 1057

4. Sum ex libris W.T.W.S. 1569 Constat 4 floreni

Ex munificentia Illustris ac Adm[odum] R[everendi] D[omini] Ioannis Swahn Praepositi Tolkmittensis ad Bibliothecam Cadinensis donatus est A[n]no 17376 Januarius. Cui Deus reddit gratias

\section{KERY Joannes}

Decreta Sacrae Sedis Apostolicae, Częstochowa, Clara Mons, 1694. $8^{\circ}$.

1. kat. elbl., t. 1, s. 79; E.XIX,232

2. sygn. Pol.7.II.3

3. 1483

4. Concedo usum simplicem huius libelli A[dmodu]V[enerabili]P[atri] Casimiro Sosnarski destinatum actuali Frater Marianus Gigniewski ${ }^{87} \mathrm{M}[\mathrm{i}] \mathrm{n}[\mathrm{iste}] \mathrm{r}$ $\operatorname{Pr}[$ ovincial] is manu propria

5. Na wyklejce przedniej odręczny spis treści.

\section{KREYSSEL Martin}

Das unfürsichtige mit seinen Lehr- und Glaubens-Sätzen die Heil. Schrifft, Braunsberg, Collegio der Societät Jesu, 1711. $4^{\circ}$.

1. kat. elbl.t. 1, s. 161; E.XX,261

2. sygn. Pol.8.II.290

3. 2552

4. Concedo usum simplicem huius libri Modum Venerabili Priori Ludovico Votruh revo[cabilem] ad Conventum Schovensem. Frater Ioannes Kamrowski $\mathrm{M}[\mathrm{i}] \mathrm{n}$ [iste]r $\operatorname{Pr}[$ ovincial] is manu propria

\footnotetext{
${ }^{87}$ Odczyt nazwiska niepewny.
} 


\section{LEO I Pontifex Romanus}

Opera D. Leonis Magni, Romani Pontificis, Antverpia, Philipp Nutius, 1583. $8^{\circ}$.

1. kat. elbl. t. 1, s. 104

2. sygn. Ob.6.II.3257

3. 457

4. Conventui Cadinen[si]. Ord[inis] Min[orum] S[ancti] Francisci Regularis Observan[tie] cedit C.J. Schrader aprili 1742. Manu propria

5. Marginalia

\section{LEO Joannes}

Historia Prussiae, Brunsberga, Collegium Soc. Jesu, 1725, $2^{\circ}$.

1. kat. elbl., t. 1, s. 370; E.XXI,176

2. sygn. Pol.8.III.23, 2 woluminy

3. 2681,2682

4. Hic liber donat[us] e[st] Conventui Cadinensi Ad S[anctum] Antoniu[m] ab Admodum Reverendo Nazart Collegy Braunsbergensis Rectore viro vere magno. Deo gratias.

\section{LIPSIUS Justus}

Admiranda sive de magnitudine Romana libri quattuor, Antverpia, officina Plantiniana apud Ioannem Moretum, 1605. $4^{\circ}$.

1. kat. elbl. t. 2, s. 156

2. sygn. Ob.7.III.755

3. 2331

4. Dono R[everendi]D[omini] Barthol[omei] Panetij Pleb[ani] Culemen[sis] inscriptus libris Resid[entiae] Choynicen[sis] Societatis Iesu 1623.

\section{LIPSIUS Justus}

De Amphitheatro Liber, Antverpia, officina Plantiniana, apud Ioannem Moretum, 1604. $4^{\circ}$.

1. kat. elbl. t. 2 , s. 156

2. sygn. Ob.7.III.756

3. 2331

4. Brak

\section{LIPSIUS Justus}

De Cruce Libri Tres, Antverpia, officina Plantiniana, apud Ioannem Moretum, 1599. $4^{\circ}$.

1. kat. elbl.t. 2, s. 156

2. sygn. Ob.7.III.757

3. 2331

4. Brak

\section{LIPSIUS Justus}

De Vesta et Vestalibus Syntagma, Antverpia, officina Plantiniana, apud Ioannem 
Moretum, 1603, $4^{\circ}$.

1. kat. elbl. t. 2, s. 156

2. sygn. Ob.7.III.760

3. 2331

4. Brak

\section{LIPSIUS Justus}

Diva Sichemiensis sive Aspricollis, Antverpia, officina Plantiniana, apud Ioannem Moretum, $1605.4^{\circ}$.

1. kat. elbl. t. 1, s. 82

2. sygn. Ob.7.III.758

3. 2331

4. Brak

\section{LIPSIUS Justus}

Diva Virgo Hallensis, Antverpia, officina Plantiniana, apud Ioannem Moretum, $1605,4^{\circ}$.

1. kat. elbl. t. 1 , s. 82

2. sygn. Ob.7.III.759

3. 2331

4. Brak

\section{LIPSIUS Justus}

Epistolica Institutio, Antverpia, officina Plantiniana, apud Ioannem Moretum, 1605. $4^{\circ}$.

1. kat. elbl. t. 2 , s. 248

2. sygn. Ob.7.III. 763

3. 2332

4. Brak

\section{LIPSIUS Justus}

Epistolarum selectarum centuria prima (-tertia) ad Belgas, Antverpia, officina Plantiniana, apud Ioannem Moretum, 1605. $4^{\circ}$

1. kat. elbl. t. 2, s. 248

2. sygn. Ob.7.III.762/c

3. 2332

4. Brak

\section{LIPSIUS Justus}

Epistolarum selectarum centuria prima (-quinta) miscellanea, Antverpia, officina Plantiniana, apud Ioannem Moretum, 1605-1611. $4^{\circ}$.

1. kat. elbl. t. 2, s. 248 2. sygn. Ob.7.III.762

3. 2332 
4. Ex libris Pauli Casimiri Gzowski ${ }^{88}$

\section{LIPSIUS Justus}

Epistolarum selectarum centuria singularis ad Germanos et Gallos, Antverpia, of-

ficina Plantiniana, apud Ioannem Moretum, 1605. $4^{\circ}$.

1. kat. elbl. t. 2 , s. 248

2. sygn. Ob.7.III.762/b

3. 2332

4. Brak

\section{LIPSIUS Justus}

Epistolarum selectarum centuria singularis ad Italos et Hispanos, Antverpia, officina Plantiniana, apud Ioannem Moretum, 1613. $4^{\circ}$.

1. kat. elbl. t. 2, s. 248

2. sygn. Ob.7.III.762/a

3. 2332

4. Brak

\section{LIPSIUS Justus}

Lovanium sive opidi et academiae eius descriptio, Antverpia, officina Plantiniana, apud Ioannem Moretum, 1605. $4^{\circ}$.

1. kat. elbl. t. 1, s. 417

2. Ob.7.III.761

3. 2331

4. Brak

\section{MAIOLI Simone}

Dierum canicularium tomi septem, Francofurt, Ioannes Godefred Schönwetter, $1642.2^{\circ}$.

1. kat. elbl.t. 2, s. 475

2. sygn. Ob.7.III.941 (egzemplarz I); sygn. Ob.7.III.1061 (egzemplarz II)

3. 2373 (egzemplarz I); 2399 (egzemplarz II)

4. Posidet G Severus ${ }^{89}$ Dant[?] 167[?]

\section{MARCOS de Lisboa}

Der Cronicken der eingesetzten Orden deß heyligen Vatters Francisci, Constanz am Bodensee, Nicolaus Kalt, 1604. $4^{\circ}$.

1. kat. elbl. t. 1, s. 75

2. sygn. Ob.7.II.3665

3. 2067

4. Hanc Cronicam donavit Conventui Cadinensi Ord[inis] Min[orum] Reg[ularium] Obs[servantium] Ad S[anctum] Antonium Pad[uanum] Perillustris

\footnotetext{
${ }^{88}$ Odczyt nazwiska niepewny.

${ }^{89}$ Ewentualnie G Legerus
} 
Admodum Reverendus Dominus Joannes Szwahn Praepositus Tolkmittensis cui sint permultae gratiae.

\section{MARTIN de Cochem}

Historiae ecclesiasticae ex Baronio desumptae, Dillingen, Johann Caspar Bencard, $1706.4^{\circ}$.

1. kat. elbl. t. 1 , s. 52

2. sygn. 219485

3. 8062

4. Brak

\section{MARTINI Martinus}

Histori von dem Tartarischen Kriege, Amsterdam, Johan Bleau, 1654. $12^{\circ}$.

1. kat. elbl.t. 1, s. 469

2. sygn. Pol.7.I.151

3. 1479

4. Conventus Cadinensis. Ex libris AWKWmus 1701

\section{MASSILLON Jean Baptiste}

Predigten welche vor dem Könige in Frankreich Ludwig den Funfzehnten gehalten worden [...] oder der Festpredigten, Dresden, Georg Conrad Walther, cz.1$10,1753-1757.8^{\circ}$.

1. kat. elbl. t. 1 , s. 213

2. sygn. 94196, 7 woluminów

3. 3951, 3952, 3953, 3954, 3955, 6743, 6744

4. Ekslibris - Incrementum Liberariae Amandi de Schwemersdorff, Decani Collegi Ecclesiae NIssensis ab Anno 1759 usque 1763 arMIs DeposItIs beLLa Cessent et paX fLoreat.

5. Pierwsze pięć części (woluminy I i II) nosi tytuł: Fastenpredigten welche vor dem König in Frankreich Ludwig den Funfzehnten gehalten worden.

\section{[MEYER Ananias]}

[Das sandgründige Lutherthumb, dass ist, ein klarer Beweiss], Oliva, [s. n.], 1695, $4^{\circ}$.

1. kat. elbl. t. 1, s. 162; E.XXII,317

2. sygn. Pol.7.II.7034

3. 1691

4. Brak

5. Brak karty tytułowej

\section{MICHAEL à s. Augustino}

Eensaemheydt van thien daghen, [Brüssel], [s. n.], 1677, $12^{\circ}$.

1. kat. elbl. t. 1, s. 196

2. sygn. Ob.7.I.1284

3. 1864 
4. Brak

5. Uszkodzona karta tytułowa.

\section{NOÜET Jacob}

Exercitia spiritualia sancti patris Ignatii, Dilinga, Joannes Casparus Bencard, $1689,12^{\circ}$.

1. kat. elbl. t. 1, s. 77

2. sygn. Ob.7.I.666

3. 1801

4. Conven[tus] Cadinensis P[at]rum Barnardin[orum]

\section{ORDINARIUM}

Ordinarium et caeremoniale pro usu Fratrum Minorum Observantium Sancti

Francisci Provinciae Poloniae Maioris, Poznań, Albert Laktanski, 1685. $4^{\circ}$.

1. kat. elbl. t. 1, s. 76; E.XXIII.401

2. sygn. Pol.7.II.376 (Egzemplarz I); sygn. Pol.7.II.386 (Egzemplarz II)

3. 1527 (Egzemplarz I); 1530 (Egzemplarz II)

4. Proweniencja egzemplarza I:

Conventus Cadinensis Ad Sanctum Antonium Paduanum

Mandatum Admodum Reverendi Patris Joanis Capistrani Szisiecki Ministri Provincialis.

Cum DEI Gratia in essentialibus alma Provincia munda maneat uti nobis per visitationes canonicas constat. In ceremonialibus tamen corrigenda, tam domi in choro quam foris advertimus enim in aliquibus ministrantibus, tam diaconis quam subdiaconis, laicis summum disordinem, nec sciunt fere quomodo procedendum ad Altare, ideo piae memoriae Admodum Reverendi Patris Joannis Capistrani Jankowski Ex Ministri Provincialis Ceremoniale recommendamus legendum, quando statutis temporibus statuta et constitutiones Provinciales ad Mensam Canonicam cum explicatione paterni idiomatis pro Laicis, quomodo in Ecclesia, Choro, tum domi, tum foris se gerere debeant, erroresque omnino corrigendos commitimus Patribus Locorum Superioribus ser Vicarys. N.3. Die 26 Julij. Anno 1727.

Applico Conventui Cadinensi Ordin[is] Minor[orum] Observ[antiae] 1694 $\operatorname{Fr}[a t e r]$ Stanislaus Grodicius vicarius manu propria

Proweniencja egzemplarza II:

Ad refectorium

Pro Conventu Cadinensi Fratrum Regularium Bernardinorum. Legat semper ad mensam quando suis temporibus leguntur statuta Provincialia Frater Kapistranus Szysiecki Minister Provincialis manu propria

5. W egzemplarzu II uszkodzenia mechaniczne pierwszych kart.

\section{ORIGENES}

Origenis Adamantii Operum pars secunda, T. 2, Basilea, Eusebius Episcopius et

Nicolaus fratris haeredes, $1571.2^{\circ}$.

1. kat. elbl. t. 1., s. 105 

2. sygn. Ob.6.III.1018
3. 1273
4. Brak

\section{OSSOWSKI Marian}

Decreta Sacrae Sedis Apostolicae ŕ Regularibus, Poznań, typis Academicis, 1770. $8^{\circ}$.

1. kat. elbl. t. 1, s. 75; E.XXIII,490

2. sygn. 92863 (Egzemplarz I); sygn. 92864 (Egzemplarz II)

3. 5134 (Egzemplarz I); 5135 (Egzemplarz II)

4. Brak

\section{PETRUS ab Angelis}

Speculum Privilegiorum Regularium in Communi, Colonia Agrippina, Johannes Wilhelm Friesse, 1681. $4^{\circ}$.

1. kat. elbl. t. 1, s. 74

2. sygn. Pol.7.II.2066

3. 1591

4. Brak

\section{PLAUTUS Titus Maccius}

Comoedić, ex recognitione Jani Gruteri, [Wittenberga], Zacharias Schurer, 1621. $4^{\circ}$.

1. kat. elbl. t. 2 , s. 226

2. sygn. Ob.7.II.4689

3. 2150

4. Ex libris Joannis [?] Baumgartneri Magdeburg constat 4 " Gulden

\section{PRAXIS}

Praxis solida et per ecclesiam communissima, remittendi et retinendi peccata, Moguntia, Ludovicus Bourgeat, 1675. $8^{\circ}$.

1. kat. elbl. t. 1 , s. 179

2. sygn. Pol.7.II.5722

3. 1633

4. Brak

\section{QUARTI Paulo Maria}

Biga aetherea, duplici sacro tractatu rapiens in caelum animos in primo agitur de processionibus ecclesiasticis et de litaniis sanctorum, Colonia Agrippina, Joannes Busae, 1672. $4^{\circ}$.

1. kat. elbl. t. 1, s. 192

2. sygn. Ob.7.II.3203

3. 2017

4. Vide Alviset Virginius 


\section{RODRIGUEZ Emanuel Lustianus}

Summa casuum conscientiae, omnium quae hucusquae in lucem exiere copiosissima, Duacum, Baltazar Beller, 1614. $4^{\circ}$.

1. kat. elbl. t. 1 , s. 179

2. sygn. Ob.6.II.3846

3. 792

4. Nunc iure emptionis Christiani Casimiri Greiffenberg P[arochi]R[oggenha usensis] Anno 1714 die 29 May

\section{RZEPNICKI Franciszek}

Vitae praesulum Poloniae, T. I-III, Poznań, typis Clari Collegi Societatis Jesu, T. I -1761 ; T. II - 1762; T. III - 1763. $8^{\circ}$.

1. kat. elbl. t. 1, s. 448; E.XXVI,547

2. sygn. Pol.8.II.19, 3 woluminy

3. 2516 (Tom I); 2517 (Tom II); 2518 (Tom III)

4. Proweniencja w tomie I:

Pro Bibliotheca Conventu[s] Cadinensis

Ex gratia Reverendissimi A. Sampławski ad usum P. Fr[atr]is Cyriaci Kelch Jubilatus Anno 1782

Proweniencja w tomie II:

Ex gratia R[everendissimi] A. Samplawski ad usum P. Fr[atr]is Cyriaci Kelch Jubilatus Anno 1782

Proweniencja w tomie III:

Ex gratia R[everendissimi] A. Samplawski ad usum P. Fr[atr]is Cyriaci Kelch Jubilatus Anno 1782

\section{SACROSANCTI}

Sacrosancti et oecumenici Concilii Tridentini Paulo III, Julio III et Pio IV. Pontificibus Maximis Celebrati canones et decreta, Colonia, Bernard Gualther, $1610,12^{\circ}$.

1. kat. elbl. t. 1 , s. 131

2. sygn. Ob.7.I.1201

3. 1857

4. Brak

5. Brak karty tytułowej. Razem z drukiem współwydany: Index librorum prohibitorum. Auctoritate Pii IV. primum editus. Postea vero Sixto V. auctus. Et nunc demum [...] Clementis Papae 8.

\section{SALIAN Jacobus}

Annales Ecclesiastici Veteris Testamenti, T. I-VI, Lutetia Parisiorum, Michael

Soly, $1641.2^{\circ}$.

1. kat. elbl. t. 1 , s. 278

2. sygn. Ob.7.IV.298, 3 woluminy,

3. 2497 (tom V-VI), 2498 (tom I-II), 2499 (tom III-IV)

4. Brak 


\section{SANCTUS de Sancta Catharina}

Utilissima de humilitate documenta Accommodatissima Religioso perfectae Humilitatis acquirendae studioso. Italico olim idiomate vulgata, Dilinga, Joannes Casparus Bencard, 1689. $12^{\circ}$.

1. kat. elbl. t. 1 , s. 197

2. sygn. Ob.7.I.668

3. 1801

4. Conven[tus] Cadinensis P[at]rum Bernardin[orum]

\section{SCHILLING Florentinus}

Synopsis Chronologico-Harmonica Biblica; Summatim continens, Universam Historiam Ecclesiasticam, Veteri Novoque Testamento comprehensam, Argentina, Caspar Dietzelii, 1650. $8^{\circ}$.

1. kat. elbl. t. 1 , s. 281

2. sygn. Ob.7.II.4287

3. 2124

4. Brak

\section{SEBASTIANUS à Matre Dei}

Firmamentum Symbolicum, in quo Deiparae Elogia, Lublin, Georg Forster, 1652. $4^{\circ}$.

1. kat. elbl. t. 1, s. 197; E.XXVII.328

2. sygn. Pol.7.II.2067

3. 1591

4. Brak

\section{SŁAWOSZ Adalbert Gabriel}

Vox catelli pastoritii penes Ovile Christi seu Controversia, [Oliva], typis Monasterii Oliviensis, $1679,8^{\circ}$.

1. kat. elbl.t. 1, s. 73; E.XXVIII,228

2. sygn. Pol.7.II.5723

3. 1633

4. Brak

\section{[SMUKALSKI Idzi]}

Veritas Christianae Religionis e Supremi Numinis existentia naturali ratione deducta, Poznań, [s. n.], 1782. $8^{\circ}$.

1. kat. elbl. t. 1, s. 176; E.XXVIII,334

2. sygn. 92912

3. 5190

4. Brak

\section{[SMUKALSKI Idzi]}

Veritas Christianae Religionis e Supremi Numinis existentia naturali ratione deducta, Poznań, [s. n.], 1788. $8^{\circ}$. 
1. kat. elbl. t. 1, s. 176; E.XXVIII,335

2. sygn. 92911

3. 5189

4. Brak

\section{STATUTA}

Statuta, constitutiones et decreta generalia familiae Cismontanae, Venetia, Ioannes Antonius Rampazett, 1598, $4^{\circ}$.

1. kat. elbl. t. 1 , s. 76

2. sygn. Ob.6.II.3190

3. 411

4. Pro loco Watemburgum Fr[ater] Stanislaus Lipac[?]

\section{SZULC Prątnicki Tomasz}

Compendium unosyllogisticum totius summae S. Thomae Aquinatis, T. I-III, Gedanum, Simon Reiniger, T. I - 1696, T. II - 1695, T. III - 1695. $12^{\circ}$.

1. kat. elbl. t. 1, s. 108; E.XXX,306

2. sygn. Pol.7.I.55, 3 woluminy, t. I-III

3. 1472 (Tom I), 1473 (Tom II), 1474 (Tom III)

4. Brak

5. We wszystkich woluminach wycięto z przodu karty ochronne.

\section{TERTULLIANUS Quintus Septimus Florens}

Opera quae adhuc reperiri potuerunt omnia, Franeker, Aegidus Radius, [1598], $2^{\circ}$.

1. kat. elbl. t. 1, s. 107

2. sygn. Ob.6.III.372 (egzemplarz I); sygn. Ob.6.III.845 (egzemplarz II)

3. 1039 (egzemplarz I); 1106 (egzemplarz II)

4. Proweniencja w egzemplarzu I:

Applicatus Conventui Gedanensi S[ancti] Nicolai Ord[inis] P[atrum] Praed[icatorum] Anno 1623

(...) Bochwicz Cracovia Anno 1603

5. Na okładce egzemplarza I superekslibris

\section{THEODORETUS}

Opera omnia, Paris, Michael Sonnium, 1608. $2^{\circ}$.

1. kat. elbl. t. 1 , s. 107

2. sygn. Ob.7.IV.136

3. 2465

4. Brak

\section{THEOPHYLACTUS Achridensis}

In quatuor Evangelistas in D. Pauli epistolas, in minores aliquot Prophetas, Basilea, officina Heruagiana per Eusebium Episcopum, 1570. $2^{\circ}$.

1. kat. elbl. t. 1 , s. 107 
2. sygn. Ob.6.III.837

3. 1100

4. Sum ex libris M[agnifici] Martini Fabritii Zullubiensis ${ }^{90}$ Crevit in adversis virtus

\section{THOMAS de Aquino s.}

Cathena aurea in quatuor Evangelia, Lugdunum, Jacobus Giunta, 1544. $8^{\circ}$.

1. kat. elbl. t. 1, s. 108

2. sygn. Ob.6.II.3936

3. 871

4. Brak

\section{THOMAS de Aquino s.}

Divi Thomae Aquinatis Doctoris Angelici in librum Beati Dionysii, Lugdunum, Stephan Michael, 1588. $2^{\circ}$.

1. kat. elbl. t. 1, s. 108

2. sygn. Ob.6.IV.144/4b

3. 1320

4. Brak

\section{THOMAS de Aquino s.}

Summa casuum conscientiae ad curam animarum, Colonia Agrippina, Ioannes Henning, 1656. $12^{\circ}$.

1. kat. elbl. t. 1 , s. 108

2. sygn. Ob.7.I.539

3. 1784

4. Oblatus hic auctor Conventui Cadinensi F[ratrum]F[ratrum] Minor[um] Observant[ium] ab Adm[odum] R[evere]ndo D[omi]no Anania Meier Beneficiato Brunsbergensi Ao 1696 ipso die S[ancti]P[atris] Francisci

\section{THOMAS de Aquino s.}

Summae Theologicae D. Thomae Aquinatis sex copiosissimi indices, Lugdunum, Stephan Michael, 1588. $2^{\circ}$.

1. kat. elbl. t. 1 , s. 107

2. sygn. Ob.6.IV.144/4e

3. 1320

4. Brak

\section{THOMAS de Aquino s.}

Totius Theologiae Summa, in tres partes digesta, Lugdunum, Stephan Michael, 1588. $2^{\circ}$.

1. kat. elbl. t. 1, s. 107

2. sygn. Ob.6.IV.144, 3 woluminy, t. I-III

\footnotetext{
${ }^{90}$ Odczyt niepewny.
} 
3. 1317 (tom I); 1318 (tom II); 1319 (tom III)

4. Proweniencja w tomie I:

4 volumina ad usum Pauli Slupcensis 16031 Octobris

F[ratris] Ioannis Damasceni Wuycisky Ordin[inis] Praed[icatorum] Conv[entus] Posna[niensis] 1682

Proweniencja w tomie II:

Pauli Slupsensis 16031 octobris

F[ratris] Ioannis Damasceni Wuycisky Ordin[inis] Praed[icatorum] Conv[entus] Posna[niensis] 1682

Proweniencja w tomie III:

Pauli Slupsensis 16031 octobris

F[ratris] Ioannis Damasceni Wuycisky Ordin[inis] Praed[icatorum] Conv[entus] Posna[niensis] 1682

\section{THOMAS de Vio}

Opuscula omnia Thomae de Vio, Lugdunum, Stephan Michael, 1588, $2^{\circ}$.

1. kat. elbl. t. 1, s. 126

2. sygn. Ob.6.IV.144/4a

3. 1320

4. Pauli Slupsensis 16031 octobris

4 volumina ad usum Pauli Slupcensis 16031 Octobris

F[ratris] Ioannis Damasceni Wuycisky Ordin[inis] Praed[icatorum] Conv[entus] Posna[niensis] 1682

\section{VENUTI Filippo da Cortona}

Dittionario volgare et latino, Bolonia, Giacopo Pietro, $1578.8^{\circ}$.

1. kat. elbl.t. 2, s. 103

2. sygn. Ob.6.II.3881

3. 821

4. Brak

\section{WOLFF Christian}

Anmerckungen über die vernüfftige Gedancken von Gott, der Welt und der Seele des Menschen, Franckfurt am Mayn, Andreaische Buchhandlung, 1724. $8^{\circ}$.

1. kat. elbl.t. 1 , s. 177

2. sygn. 92105

3. 3332

4. Moses London

słowa kluczowe: Kadyny, bernardyni, księgozbiór, starodruki, kasata, Biblioteka Elbląska 


\title{
THE BOOK COLLECTION OF THE BERNARDINE MONASTERY IN KADYNY IN THE ELBLĄG LIBRARY
}

\begin{abstract}
Summary
Cyprian Norwid Library of Elbląg includes the collection of the former Elbląg City Library before 1945. Among them are 124 volumes (including 12 bound together), which were once owned by the Library of the Bernardine Monastery in Kadyny.

The Bernardine Monastery in Kadyny was erected 18 August, 1683. At the beginning of the eighteenth century it became a known sanctuary of St. Anthony of Padua in the region. In 1826 the monastery was dissolved by the Prussian authorities. Before the dissolution the monastic library stored 1327 volumes. In a separate cabinet, outside the library, the Bernardines had 29 volumes of libri prohibita.

In April 1830, part of the book collection of Kadyny was included in the library of the Lower Secondary School of Elblag, and then it was transformed to the Elbląg City Library. An unspecified number of books from the library of the Bernardines in Kadyny, in the nineteenth century, were taken over by the Chapter of Warmia in Frombork, and currently they are stored in the Library of "Hosianum" the Seminary of the Archdiocese of Warmia in Olsztyn.

Among the 124 cataloged volumes of Kadyny in the Library of Elblag, by far the most of them concern the subject of theology and asceticism. The oldest book in the analyzed collection of Kadyny is Lombardica historia by Jacob de Voragine, published in Nuremberg in 1501, the newest one is Veritas Christianae Religionis by Idzi Smukalski released in 1788 in Poznań. Overall, 31 volumes come from the sixteenth century, 54 volumes come from the seventeenth century and 39 volumes come from the eighteenth century.
\end{abstract}

Keywords: Kadyny, the Bernardines, book collection, antique books, dissolution, the Elbląg Library 